Ribeiro D.M., Planchon S., Leclercq C.C., Dentinho M.T.P., Bessa R.J.B., Santos-Silva J., Paulos K., Jerónimo E., Renaut J., Almeida A.M. 2020. The effects of improving low dietary protein utilization on the proteome of lamb tissues. Journal of Proteomics 223: 103798.

https://doi.org/10.1016/i.jprot.2020.103798

\title{
The effects of improving low dietary protein utilization on the proteome of lamb tissues
}

Author links open overlay

panelD.M.Ribeiro ${ }^{a b}$ S.Planchon ${ }^{b}$ C.C.Leclercq M.T.P.Dentinho ${ }^{\mathrm{cd}}$ R.J.B.Bessa'J.Santos-

Silva ${ }^{\mathrm{cd} K}$.Paulos ${ }^{\mathrm{d}}$ E.Jerónimo ${ }^{\mathrm{ef} J}$.Renaut ${ }^{\mathrm{b}}$ A.M.Almeida ${ }^{\mathrm{a}}$

Show more

Add to Mendeley

Share

Cite

https://doi.org/10.1016/j.jprot.2020.103798Get rights and content

\section{Highlights}

Differences in muscle glycolysis derive mostly from increased glucose availability in lambs fed with lower dietary protein

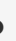

Lower levels of dietary protein affect the metabolism of sulphur amino acids and increase Fe abundance in the hepatic tissue

Lower dietary protein, particularly with condensed tannin treatment, have higher adipocyte turn-over rate in comparison to control

\section{Abstract}


Cistus ladanifer $\mathrm{L}$. is a common shrub endemic to the Mediterranean region with high levels of condensed tannins (CT). CT form complexes with dietary protein resisting microbial degradation in the rumen, which enhances dietary protein utilization in ruminant diets. The objective of this study was to evaluate the utilization of CT in the diet of lambs on the proteomes of muscle, hepatic and adipose tissues.

Twenty-four Merino Branco ram lambs were randomly allocated to three treatments $(n=8)$ : C - control (160 g crude protein $(\mathrm{CP})$ ) per kg DM, RP - reduced protein $(120 \mathrm{~g} \mathrm{CP} / \mathrm{kg} \mathrm{DM})$; and RPCT - reduced protein (120 g CP/kg DM) treated with CT extract. At the end of the trial, lambs were slaughtered and the longissimus lumborum muscle, hepatic and peri-renal adipose tissues sampled. A two-way approach was used for proteomic analysis: 2D-DIGE and nanoLC-MS.

In the muscle, $\mathrm{C}$ lambs had lower abundance proteins that partake in the glycolysis pathway than the lambs of other treatments. Control lambs had lower abundance of Fe-carrying proteins in the hepatic tissue than RP and RPCT lambs. The latter lambs had highest abundance of hepatic flavin reductase. In the adipose tissue, $\mathrm{C}$ lambs had lowest abundance of fatty-acid synthase.

\section{Significance}

soybean meal is an expensive feedstuff in which intensive animal production systems heavily rely on. It is a source of protein extensively degraded in the rumen, leading to efficiency losses on dietary protein utilization during digestion. Protection of dietary protein from extensive ruminal degradation throughout the use of plants or extracts rich in $\mathrm{CT}$ allow an increase in the digestive utilization of feed proteins. In addition to enhance the protein digestive utilization, dietary CT may induce other beneficial effects in ruminants such as the improvement of the antioxidant status.

\section{Graphical abstract}




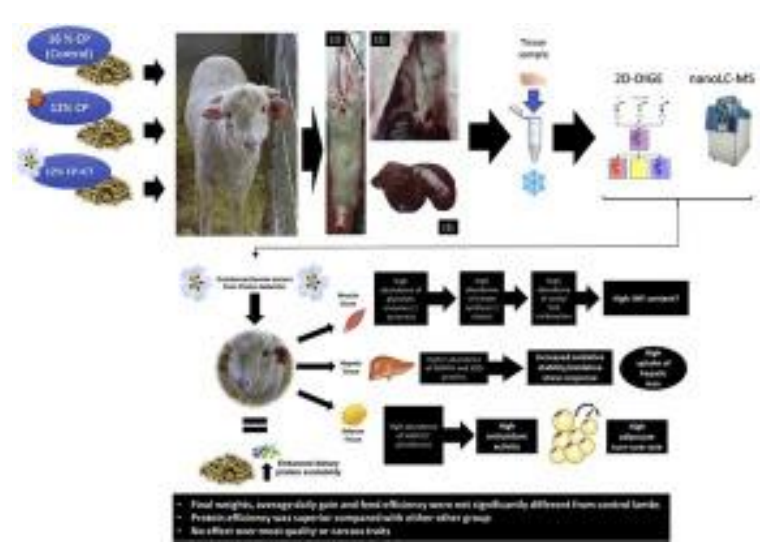

1. Download : Download high-res image (109KB)

2. Download : Download full-size image

- Previous article in issue

- Next article in issue

\section{Keywords}

Lamb

Condensed tannins

Tissue proteomics

\section{Introduction}

Cistus ladanifer L.(rockrose) is a shrub commonly found in the SW Iberian Peninsula [1]. It is a plant with high content of condensed tannins (CT). These phenolic compounds are part of the plants natural defences against herbivores. They have antinutritional properties, reducing the ingestion and digestibility of the protein and carbohydrate fractions of the feed, which are particularly serious in monogastric animals. They also have interesting antioxidant and antimicrobial effects [2]. It was additionally found that dietary CT reduce ruminal methanogenesis by directly inhibiting archaeal and protozoal methanogenesis [3] .

In ruminants, CT provide an interesting approach to manipulate animal digestion and metabolism. Dietary CT are able to modulate ruminal biohydrogenation, promoting the increase of healthy fatty acids, such as cis9-trans11 conjugated linoleic acid (CLA), in ruminant fat $[\underline{2}, \underline{4}]$. Indeed, authors have reported that quebracho tannins, 
when present in a forage-based diet, increase stearoyl-CoA-desaturase activity in the longissimus dorsi muscle of lambs. This enzyme is responsible for the synthesis of mono unsaturated fatty acids and cis9-trans 11 CLA [5]. Moreover, dietary CT enhanced hepatic antioxidative status in sheep fed quebracho tannins [6]. The mechanism by which CT enhance the antioxidative status of tissues is not fully characterized, although it is thought to be indirect since these are not absorbed in the intestine [2]. The salivary protein profile of sheep fed with Cistus ladanifer has been reported before [7], but to our knowledge, no studies have been published regarding the effect of dietary CT on the proteome of other sheep tissues or fluids. Of particular interest to the present study, is the complex formation of CT and dietary proteins. They form insoluble complexes with ingested protein in the rumen, at a $\mathrm{pH}$ ranging between 5.5 and 7. In the abomasum, when the $\mathrm{pH}$ lowers to acidic levels between 2.5 and 3.5, this complex is dissociated and dietary protein becomes available for intestinal digestion and absorption [2, $\underline{8}]$. Treating soybean meal with a CT extract from Cistus ladanifer reduced the rumen protein degradability in an invitro experiment carried out by Dentinho et al. [8]. An in vivo experiment with rumen-cannulated rams aiming to confirm these results showed that a concentration of $15 \mathrm{~g}$ of CT/kg of dry matter (DM) reduces rumen degradable protein without compromising the dry matter degradability and the digestibility in the whole digestive tract [9].

The complex formation of $\mathrm{CT}$ and dietary protein, and consequent dissociation in the abomasum, could be a viable way of reducing dietary protein of lamb diets while achieving comparable results to untreated diets with higher protein content. This would reduce the need of imported protein feedstuffs namely soybean meal whilst using an abundant resource: Cistus ladanifer, overall leading to more sustainable animal feeding and production. Typically, in Portugal as in other Mediterranean countries, lambs are weaned at 1 to 2 months of age and are either slaughtered and consumed as light lambs or are fattened and finished [10]. The latter system uses chiefly concentrate rations. Lambs with around $20 \mathrm{~kg}$ require roughly $16-17 \%$ Crude Protein (CP) [11]. Hence, it would be interesting to compare if lambs fed CT-treated diets with $12 \% \mathrm{CP}$, which is the protein requirement at the end of fattening, could achieve the same results as those fed with untreated diets with $16 \% \mathrm{CP}$. In the present experiment, a reduced protein diet treated with Cistus ladanifer CT (RPCT, $120 \mathrm{~g}$ 
$\mathrm{CP} / \mathrm{kg} \mathrm{DM}$ ) was formulated to assess if, compared to a control diet (160 g CP/kg $\mathrm{DM}$ ), a similar lamb growth performance could be achieved. An untreated diet with $120 \mathrm{~g} \mathrm{CP} / \mathrm{kg}$ DM was additionally included in the design in order to study the effect of lower dietary protein. The results of this trial are reported in a companion paper [67]. Briefly, CP intake was higher in the control treatment, but the final live weight, average daily gain and feed conversion ratio was not different from the RPCT treatment. These results are quite promising; however, there are no reported studies, to our knowledge, that explain these differences at the molecular level.

Indeed, the effect of Cistus ladanifer CT on edible tissue proteome is currently unknown. Muscle, hepatic and adipose tissues are edible tissues whose quality is of paramount importance in the industry. When their proteomes are analysed together in proteomic experiments, they provide a wide picture of the metabolic status of the animal under a particular effect, as we have recently demonstrated [12]. The muscle is the edible part of the carcass and therefore of higher economic value. The liver provides interesting information on the major biological processes occurring and the adipose tissue is a site of reserves accumulation that also informs regarding animal performance. Thus, the objective of this study is to assess the effect of dietary CT and different levels of dietary protein on the muscle, hepatic and adipose tissue proteome of lambs fed diets with different levels of dietary protein, using two different proteomic approaches.

\section{Materials and methods}

\subsection{Condensed tannin extraction and soybean meal treatment}

Cistus ladanifer (Fig. 1) green vegetative material was collected in March 2015. The biomass was dried at room temperature, ground and washed with acetone:water solution $(70: 30, v / v)$ in the proportion of 10:1 (acetone solution:rockrose). The mixture was allowed to rest for $48 \mathrm{~h}$ with frequent manual agitation during the day. The supernatant containing CT was collected, filtered with gauze and placed on a fume hood until full acetone evaporation. The aqueous extract was repeatedly washed with petroleum ether until becoming clear, to remove unwanted plant components. The aqueous phase (with CT) was frozen at $-20{ }^{\circ} \mathrm{C}$ and freeze-dried. It contained $640 \mathrm{~g} \mathrm{CT} / \mathrm{kg}$ dry matter (DM). 


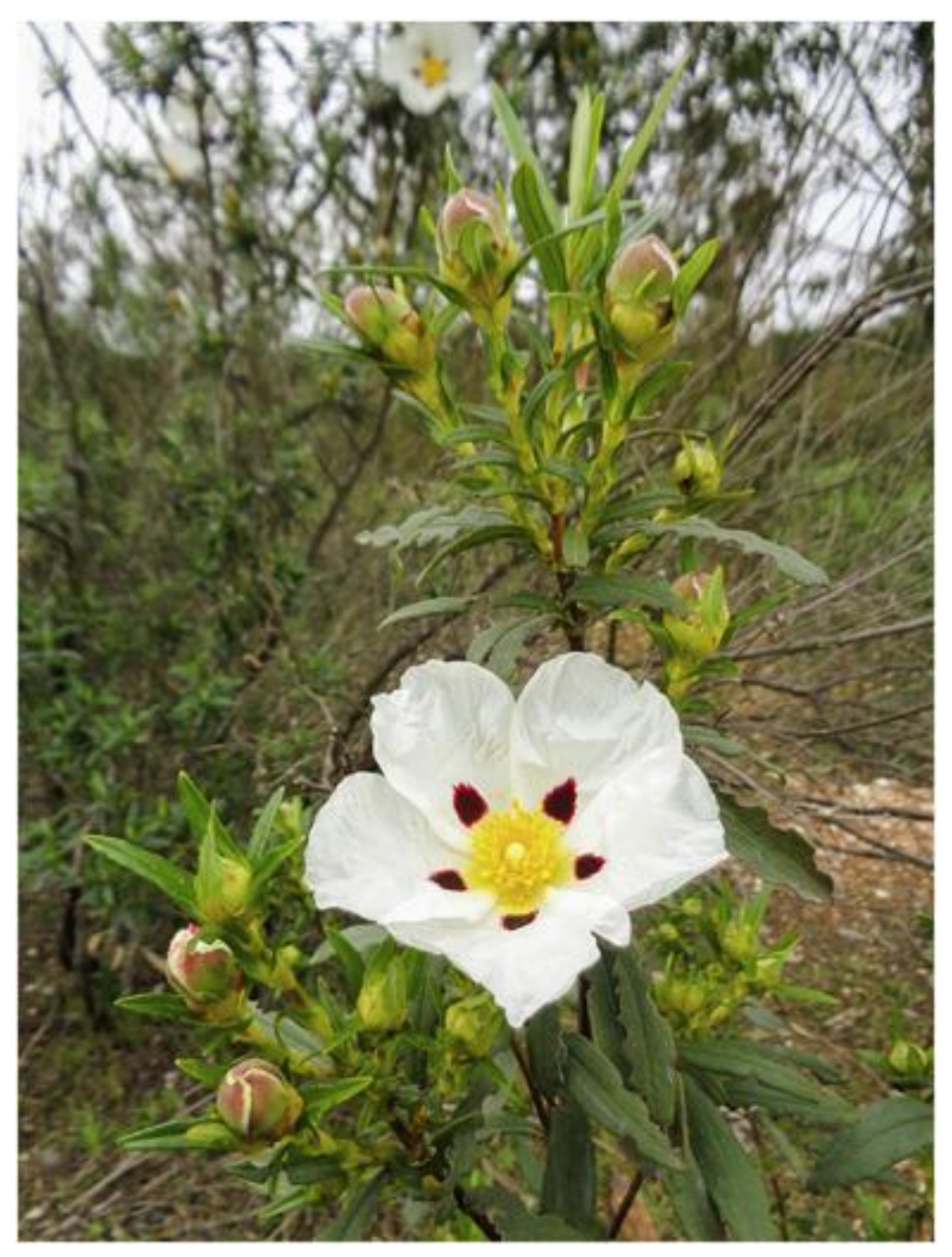

1. Download: Download high-res image (477KB)

2. Download: Download full-size image

Fig. 1. Cistus ladanifer (rockrose) plant (www.cistusrumen.pt).

The extract was then diluted in an 70:30 (v:v) acetone:water solution prior to soybean treatment. Batches of $10 \mathrm{~kg}$ of soybean meal were sprayed with $235 \mathrm{~g}$ of extract diluted in 11 of acetone:water solution (70:30). The soybean meal for the control and RP diets was sprayed with the acetone:water solution (without extract). The mixtures were homogenized and exposed to air for four days for acetone depletion.

\subsection{Animal trial and sampling procedure}

A detailed description of the animal trial has been reported [67]. Twenty-four Merino Branco lambs with average initial live weight (LW) of $21.1 \pm 1.6 \mathrm{~kg}$ were used. 
During the trial, lambs were dewormed for gastrointestinal and pulmonary parasites (Seponver® Plus, Ecuphar Veterinaria, Spain) and vaccinated against pasteurellosis and clostridial diseases (Heptavac® P Plus., MSD Animal Health, Portugal) and coccidiosis (Vecoxan ${ }^{\circledR} 2.5 \mathrm{mg} / \mathrm{ml}$, Esteve Veterinaria, Spain).

The trial started on September 2017, with an adaptation period of 7 days and 5 weeks of feeding until slaughter. The lambs were weighed, housed individually in $1.52 \mathrm{~m}^{2}$ pens with wood shaving beds and randomly distributed into three dietary treatments. Diets consisted on hay and concentrate in the ratio 15:85. The hay contained $923 \mathrm{~g} / \mathrm{kg}$ of DM, $64 \mathrm{~g} / \mathrm{kg}$ DM of crude protein (CP) and $669 \mathrm{~g} / \mathrm{kg} \mathrm{DM}$ of neutral detergent fibre (NDF). The concentrate's main source of protein was soybean meal (SBM). Diets differed on CP content and of CT inclusion, as follows: 1) $160 \mathrm{~g}$ $\mathrm{CP} / \mathrm{kg}$ DM with untreated SBM (control); 2) $120 \mathrm{~g} \mathrm{CP} / \mathrm{kg}$ DM using untreated SBM (RP); and 3) $120 \mathrm{~g} \mathrm{CP} / \mathrm{kg}$ DM using SBM treated with $15 \mathrm{~g} / \mathrm{kg}$ of CT (RPCT). All lambs had constant access to fresh water.

One lamb of the RPCT treatment was removed due to poor adaptation to the experimental procedures. All diets were offered daily at $10 \mathrm{~h}$ as $4 \%$ of each animal body weight. During the experimental period, lambs were weighed weekly before feeding, to adjust feed amounts to LW.

At the end of the trial, all lambs were slaughtered in an experimental abattoir. Samples of longissimus lumborum muscle, peri-renal fat and liver were taken and snap frozen using liquid nitrogen. Samples were kept at $-80{ }^{\circ} \mathrm{C}$ until proteomic analysis. Fig. $\underline{2}$ summarizes the protocol used.

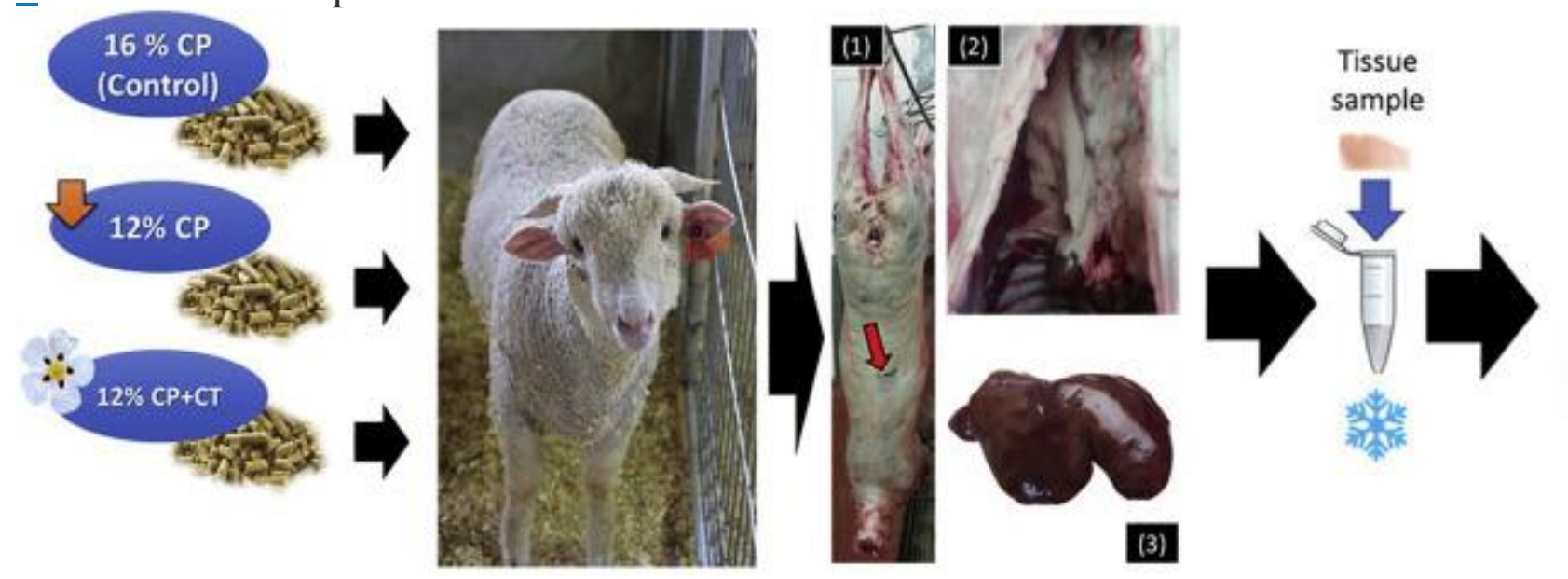

2D-DIGE

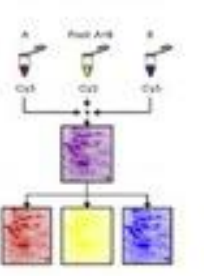

1. Download : Download high-res image (252KB) 
2. Download : Download full-size image

Fig. 2. Workflow from animal trial to data treatment of proteomic results. Sampling of tissues: 1- longissimus lumborum, 2- peri-renal fat and 3- hepatic tissue (DIGE figure: https://2d-gel-analysis.com/starters-guides/dige-guide/). Slaughterhouse photographs: David Ribeiro. Lamb photograph: David Soldado.

\subsection{Animal welfare disclaimer}

The animal trial was approved by the Organization Responsible for the Well-being of Experimental Animals (ORBEA, the ethics committee of the National Institute of Agrarian and Veterinary Research of Portugal) and monitored by the competent veterinary authority. The Directive 2010/63/EU on animal protection in animal research was followed, within the context of animal experimentation under farm conditions.

\subsection{Protein extraction and sample preparation}

The methodology used for gel-based and label-free analysis has been published previously [12]. In this study, we detail the protocol with the adaptations made for the sheep samples. Eighteen samples were taken randomly for proteomic analysis, 6 for each treatment for gel-based and all available samples for label-free. After freezedrying, samples were ground in liquid nitrogen using mortar and pestle. Approximately $0.4 \mathrm{~g}$ of the resulting tissue powder was suspended in $1 \mathrm{ml}$ of cold $10 \%$ trichloroacetic acid (TCA) in acetone with $0.07 \%$ dithiothreitol (DTT). The remainder of the tube's volume was filled with the same solution. After $30 \mathrm{~s}$ vortexing, samples were cooled at $-20^{\circ} \mathrm{C}$ for $1 \mathrm{~h}$. They were subsequently centrifuged at 15,000 $\mathrm{g}$ for $15 \mathrm{~min}$ at $4{ }^{\circ} \mathrm{C}$ in a Beckman Coulter Allegra 64R centrifuge (Beckman Coulter Inc., Indianapolis, USA). The supernatant was discarded, and the pellet washed twice with cold acetone by letting it rest for $10 \mathrm{~min}$ at $-20{ }^{\circ} \mathrm{C}$ and centrifuging at $10,000 \mathrm{~g}$ for $5 \mathrm{~min}$ at $4{ }^{\circ} \mathrm{C}$.

Due to the properties of the adipose tissue, protein extraction was performed using a different optimized protocol previously described [12]. These samples were ground as described previously. Tissue powder was suspended in $600 \mu \mathrm{l}$ of protein extraction buffer (30\% sucrose, $2 \%$ sodium dodecyl sulphate, $0.1 \mathrm{M}$ Tris-hydrochloride $(\mathrm{HCl})$, 
$5 \%$ 2-mercaptoethanol, $\mathrm{pH}=8$ ) and incubated at $65^{\circ} \mathrm{C}$ for $1 \mathrm{~h}$ with agitation at $800 \mathrm{rpm}$. After incubation in the dark, the tube was filled with phenol (tris-buffered, $\mathrm{pH}=8.0$ ), vortexed for $30 \mathrm{~s}$ and centrifuged at 10,000 $\mathrm{g}$ for $5 \mathrm{~min}$ in an Eppendorf 5415 D centrifuge (Eppendorf AG, Hamburg, Germany). Three phases (phenol + cellular debris, aqueous SDS phase with solubilized proteins and fat) were formed in the tube and $300 \mu \mathrm{l}$ out of the second phase was extracted into a new tube. The extract was diluted six times in cold $0.1 \mathrm{M}$ ammonium acetate in methanol and kept for $30 \mathrm{~min}$ at $-20^{\circ} \mathrm{C}$, after which it was centrifuged at 10,000 $\mathrm{g}$ for $5 \mathrm{~min}$, whilst washing with cold $0.1 \mathrm{M}$ ammonium acetate in methanol twice. The pellet was then washed twice with cold $80 \%$ acetone and dried. Finally, the dried pellet was dissolved in $150 \mu \mathrm{l}$ labelling buffer (30 mM Tris, $2 \mathrm{M}$ thiourea, $7 \mathrm{M}$ urea, 2\% (w/v) 3-[(3Cholamidopropyl)dimethylammonio]-1-propanesulfonate (CHAPS) and incubated at room temperature with agitation $(650 \mathrm{rpm})$ for $1 \mathrm{~h}$.

Protein concentration of all samples was determined following the Bradford method [13], using bovine serum albumin as a standard. All samples were kept at $-20{ }^{\circ} \mathrm{C}$ until further processing using two different proteomic approaches: gel-based with twodimensional difference gel electrophoresis (2D-DIGE) and label-free with liquid chromatography coupled to a mass spectrometer (nanoLC-MS).

\subsection{Gel-based proteomics}

Protein extracts were thawed at room temperature, vortexed and centrifuged at $15,000 \mathrm{~g}$ for $5 \mathrm{~min}$. All tissue sample extracts were adjusted to a final $\mathrm{pH}$ of 8.5, using sodium hydroxide (NaOH, $1 \mathrm{M}$ ) (Merck KGaA, Darmstadt, Germany). Labelling procedure followed manufacturer's instructions (3Dyes 2-D CYanine Labeling kit, Interchim, Montluçon, France), as reported. Labelling of $50 \mu \mathrm{g}$ of protein per sample was performed with either $0.4 \mu \mathrm{l}$ of $\mathrm{Cy} 3$ or Cy 5 labelling dye $(1 \mathrm{nmol} / \mu \mathrm{l})$. A pool of all samples was created as an internal standard and labelled with Cy2 dye (with the same ratio, $0.4 \mu \mathrm{l}$ for $50 \mu \mathrm{g}$ ). After an incubation on ice of $30 \mathrm{~min}$ in the dark, $1 \mu \mathrm{l}$ of $10 \mathrm{mM}$ lysine was added, followed by another incubation for $10 \mathrm{~min}$ in ice in the dark. At this point, $\mathrm{Cy} 2, \mathrm{Cy} 3$ and $\mathrm{Cy} 5$ labelled extracts were combined and the volume adjusted to $450 \mu \mathrm{l}$ using lysis buffer (7 M urea, $2 \mathrm{M}$ thiourea, $0.5 \%(w / v)$ CHAPS), followed by the addition of $9 \mu$ of ampholyte (SERVALYTTM 3-10 Iso- 
Dalt, Serva, Heidelberg, Germany) and $2.7 \mu 1$ of DeStreak reagent. A total of $150 \mu \mathrm{g}$ of protein were loaded into each ImmobilineTM DryStrip pH 3-10 NL, 24 cm (GE Healthcare, Uppsala, Sweden), via passive rehydration overnight. Afterwards, isoelectric focusing was carried out using an IPGphor 3 (GE Healthcare, Uppsala, Sweden), using the following program: $100 \mathrm{~V}$ for $1 \mathrm{~h}$, gradual increase to $1000 \mathrm{~V}$ for $4 \mathrm{~h}, 1000 \mathrm{~V}$ for $4 \mathrm{~h}$, gradual increase to $10,000 \mathrm{~V}$ for $6 \mathrm{~h}$ and $10,000 \mathrm{~V}$ up to 90,000 Vhs. Second dimension was done using an HPETM -FlatTop Tower (Serva Electrophoresis GmbH, Heidelberg, Germany) with a 2DE HPETM Large Gel NF $12.5 \%$ kit, following the manufacturer's instructions. Gels were scanned using a Typhoon FLA 9500 scanner (GE Healthcare, Uppsala, Sweden) and analysed using Samespots v.5 (Totallab Ltd., Newcastle upon Tyne, UK). Spots with an abundance fold change higher than $1.2[\underline{14}, \underline{15}]$, ANOVA $p<.05$ were selected, thus generating a pick list. Automatic spot picking was done using an Ettan spot picker (GE Healthcare, Uppsala, Sweden). Digestion was performed automatically using a Freedom EVO200 Workstation (TECAN, Mannedorf, Switzerland), as reported before [16]. The resulting peptides were manually spotted onto OptiTOF MALDI target plates, to $0.7 \mu \mathrm{l}$ of the extracted peptides $0.7 \mu \mathrm{l}$ of matrix solution was added $(7 \mathrm{mg} / \mathrm{ml}$ alphacyano-4-hydroxycinnamic acid in 1/1 MQ/ACN with $0.1 \%$ trifluoroacetic acid) and allowed to air dry. Mass spectrometry (MS) and MS/MS analyses were carried out using the TOF/TOF 5800 MS system (Sciex, Foster City, CA, USA) in positive mode. One MS spectrum was acquired for each spot with a laser intensity of 4200, optimal for balancing signal intensity with peak resolution based on laboratory experience. The ten highest peaks in the MS spectrum of each spot were subsequently automatically selected for MS/MS, excluding known contaminants and trypsin autocleavage products. Fragmentation was done in $1 \mathrm{keV}$ mode and a MS/MS spectrum consisted in the accumulation of the signal of 3000 individual laser shots. MS analyses are calibrated using a mixture of four standard peptides and recalibrated post-acquisition based on minimum two trypsin autocleavage products. MS/MS analyses are calibrated based on the fragmentation spectrum of GluFib using the TOF/TOF calibration kit (Sciex) according to the instructions of the supplier. The ProteinPilot ${ }^{\mathrm{TM}}$ software 4.5 was used for database searches with an in-house Mascot platform (version 2.3, Matrix Science, http://www. matrixscience.com, London, UK). Proteins were identified via a search in the UniProtKB database with a restriction 
on Ovis aries taxonomy (68,383 sequences) and the NCBIprot database with a restriction on Mammalia taxonomy (163,375,434 sequences) when no ID was obtained for the UniprotKB database. The search parameters used were the following: two missed cleavages, fixed modification set to carbamido-methylation of cysteine, variable modifications were set to the di-oxidation of tryptophan, the oxidation of methionine/tryptophan and tryptophan to kynurenine modification. They were carried out with a peptide mass tolerance of $100 \mathrm{ppm}$ and a fragment mass tolerance of $0.5 \mathrm{Da}$.

\subsection{Label-free proteomics}

A protocol was adapted from one previously described [12]. Briefly, $20 \mu \mathrm{g}$ of protein extract per sample were loaded and separated on a Criterion TM XT precast 1D gel (4-12\% bis-tris, $1.0 \mathrm{~mm} \times 12$ wells, Bio-Rad, Hercules, CA, USA) following manufacturer's instructions. After a short migration, 1D-gels were stained with Instant BlueTM (Gentaur BVBA, Kampenhour, Belgium). Afterwards, the bands of each sample were divided into two halves and cut into small pieces to perform in-gel digestion. Each group was reduced, alkylated and de-stained. Then, proteins were digested using tryptic enzyme (sequencing mass grade, Promega, Madison, WI, USA) and peptides were extracted. The extracted peptides were analysed with a NanoLC 425 Eksigent System (Sciex, Suarlee, Belgium) coupled to a TripleTOF® 6600 MS system (Sciex, Foster City, CA, USA).

Peptides were loaded onto the trap column (C18 acclaim $^{\mathrm{TM}}$ PepMap $^{\mathrm{TM}}, 5 \mu \mathrm{m}$, $5 \mathrm{~mm} \times 300 \mu \mathrm{m}$, Thermo Scientific, Bremen, Germany) and desalted for $5 \mathrm{~min}$ at a flow rate of $2 \mu \mathrm{l} / \mathrm{min}$ using loading buffer ( $2 \% \mathrm{v} / \mathrm{v}$ acetonitrile, $0.05 \%(v / \mathrm{v})$ trifluoroacetic acid). After this, peptides were separated onto a $\mathrm{C} 18$ reverse phase column at a flow rate of $300 \mathrm{nl} / \mathrm{min}\left(\mathrm{C} 18\right.$ acclaim $^{\text {TM }}$ PepMap $^{\mathrm{TM}} 100,3 \mu \mathrm{m}, 100 \AA$, $75 \mu \mathrm{m} \times 15 \mathrm{~cm}$, Thermo Scientific, Bremen, Germany) using a linear binary gradient (solvent A: $\mathrm{H}_{2} \mathrm{O}$ LC-MS, $0.1 \%$ (v/v) formic acid; solvent B: acetonitrile, 0.1\% (v/v) formic acid).

Peptides were eluted from 3\% B to $30 \%$ over 60 min, increased to $40 \%$ B during 10 min to elute the most hydrophobic peptides then increased to $80 \%$ B until 10 min to wash the column, and then re-equilibrated prior to the next injection for $20 \mathrm{~min}$ at 
$3 \%$ B. A MS survey scan from 300 to $1250 \mathrm{~m} / z$ with $250 \mathrm{~ms}$ of accumulation time was followed by $30 \mathrm{MS} / \mathrm{MS}$ scans (mass range 100-1500 m/z) using the automatically adjusted system of rolling collision energy voltage. The acquired MS and MSMS data were imported into Progenesis QI for Proteomics software (version 4, Nonlinear Dynamics, Waters, Newcastle upon Tyne, UK). The protein and peptide identification searching Ovis aries database on UniprotKB via Mascot Daemon (version 2.6.0. Matrix Science, London, UK) were imported to Progenesis QIP and matched to peptide spectra. The following Mascot research parameters were used: peptide tolerance of $20 \mathrm{ppm}$, fragment mass tolerance of $0.5 \mathrm{Da}$, max two missed cleavages, carbamido-methylation of cysteine as fixed modification and oxidation of methionine, $\mathrm{N}$-terminal protein acetylation and tryptophan to kynurenine as variable modifications. Only the proteins identified with a significance Mascot-calculated confidence of $95 \%$ were accepted.

\subsection{Data analysis and interpretation}

In the gel-based approach, data visualization was performed using the Samespots v.5. The following filters were applied to identify proteins with differential expression: protein scores higher than 61, fold change higher than 1.2 and an ANOVA pvalue $<0.05$. In label-free analysis, differentially expressed proteins were considered significantly different between treatments when the following applied filters were combined: an ANOVA $p$-value $<.05$, at least 1 unique peptide per identified protein and at least 2 significant peptides per protein, and a fold change higher than 1.5 [17]. Proteome characterization of all tissues was carried out also using Progenesis QIP. Both Progenesis and Samespots yielded Principal Component Analysis for each tissue.

Proteome characterization all tissues was performed using PANTHER [18] for all 3 Gene Ontology (GO) categories: biological process (BP), molecular function (MF) and cellular component (CC). Heatmaps for protein abundance of differentially abundant proteins were obtained using the R software [19] and the gplots package [20]. Protein-protein interactions were obtained using STRING [21]. 
The MS proteomics data has been deposited to the ProteomeXchange Consortium [22] via the PRIDE [23] partner repository with the dataset identifier PXD PXD015689 and https://doi.org/10.6019/PXD015689.

\section{Results}

Control lambs were heavier by the end of the experiment when compared to the RP group only, with average 29.1 and $27.0 \mathrm{~kg} \mathrm{LW}$, respectively. The same difference was detected in the average daily gain: 219 and $176 \mathrm{~g} /$ day, respectively. The RPCT group had no difference with either group in any parameter. These results are presented in a companion paper [67] dedicated specifically to the topic and are mentioned here for context reasons only.

\subsection{Proteome characterization}

In this study, a total of 1520,1653 and 2300 proteins were identified in the muscle, hepatic and adipose tissues respectively using the label-free approach. Fig. $\underline{3}$ summarizes the molecular function (MF), biological process (BP) and cellular component (CC) gene ontology annotations obtained for each tissue. Muscle tissue had two major MF: catalytic activity (29.90\%) and binding (26.70\%). A similar relation has been found for the hepatic tissue, where catalytic activity $(40.60 \%)$ and binding $(23.30 \%)$ were the major molecular functions. Similarly to other tissues, the adipose tissue had highest percentage of catalytic (30.40\%) and binding (26.00\%) activities. 

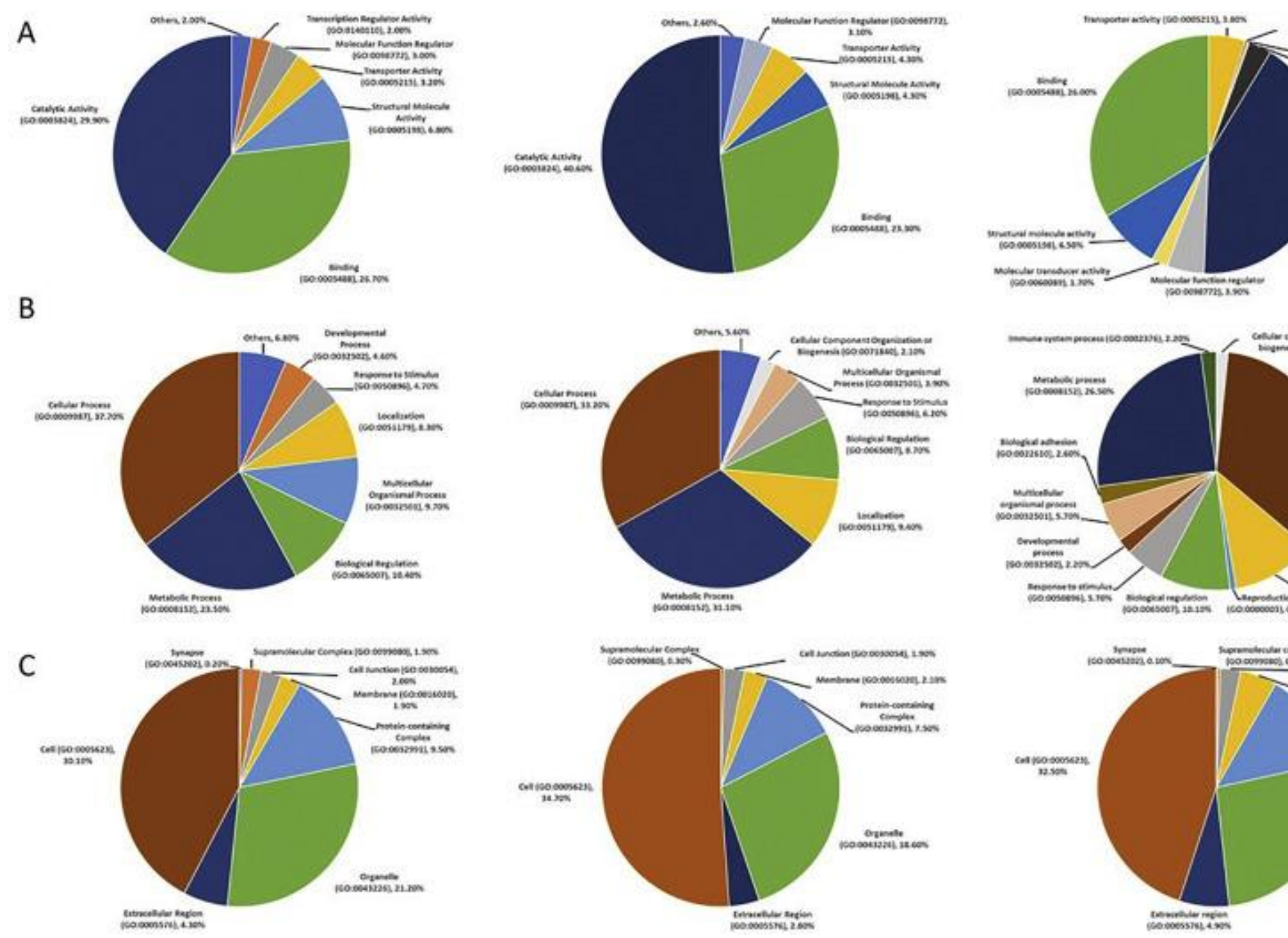

1. Download : Download high-res image (452KB)

2. Download : Download full-size image

Fig. 3. Proteome characterization of the three tissues: longissimus lumborum muscle (1st column), hepatic (2nd column) and adipose tissues (3rd column). Rows: A - molecular function; B - biological process; $\mathrm{C}$ - cellular components.

Regarding BP, cellular and metabolic process were the two major categories in the muscle and hepatic tissues: 37.70 vs $33.20 \%$ and 23.50 vs $31.10 \%$, respectively. The adipose tissue also followed this pattern with $36.60 \%$ and $26.50 \%$ for cellular and metabolic processes, respectively.

Cell was the major category regarding $\mathrm{CC}$, followed by organelle in all tissues. Indeed, the hepatic tissue had the highest percentage of cell components (34.70\%), followed by adipose $(32.50 \%)$ and muscle $(30.10 \%)$ tissues. The organelle followed 
the contrary order with muscle, adipose and hepatic tissues having $21.10 \%, 19.30 \%$ and $18.60 \%$.

\subsection{Differential protein abundance}

A representation of the differential abundance of selected proteins is depicted in Fig. $\underline{4}$, for all tissues. Some proteins were uniquely identified in each tissue in both approaches, as depicted in Fig. 5. Those presented are the most representative for discussion purposes, including PGK2 in the muscle, Sulft in the hepatic tissue and ECI1 in the adipose tissue. In Fig. 6, Fig. 7 a Principal Component Analysis is provided for gel-based and label-free, respectively. Both techniques show lack of clear clustering between replicates. Finally, a protein-protein interaction of proteins identified in the muscle tissue using both approaches is provided in Fig. 8. For the hepatic and adipose tissues, they are provided in supplementary file 1.
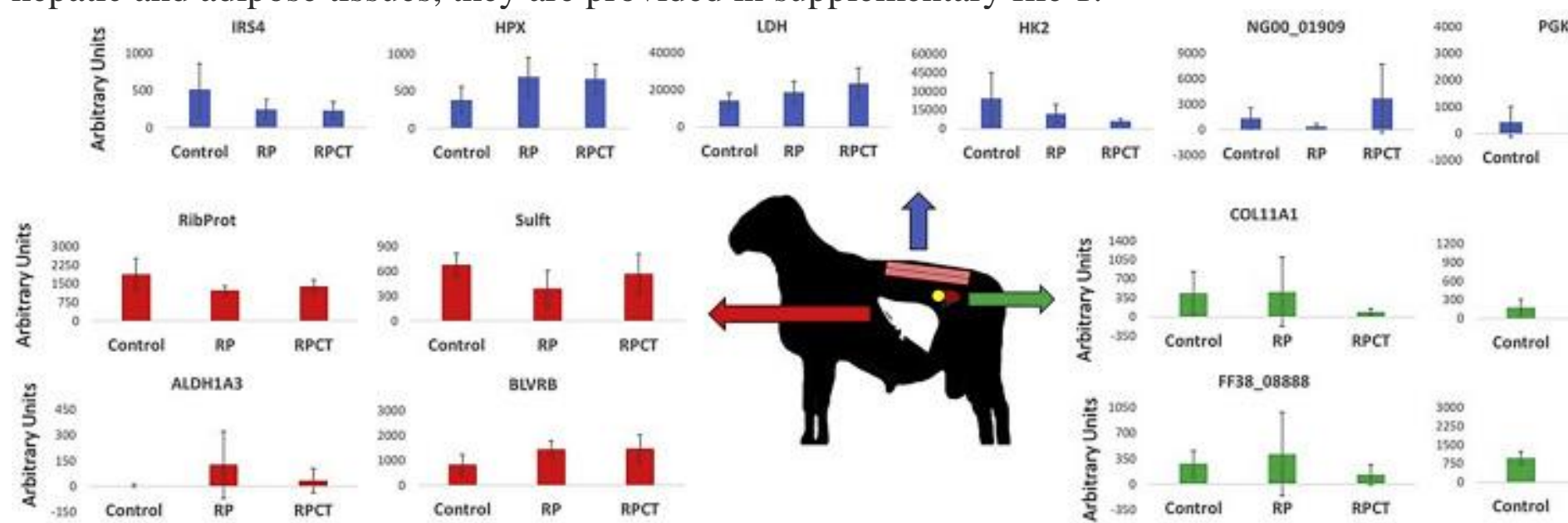

1. Download : Download high-res image (353KB)

2. Download: Download full-size image

Fig. 4. Differential abundance of some proteins from different tissues (blue - longissimus lumborum; red - hepatic tissue; green - adipose tissue) according to experimental group (control, RP - reduced protein, RPCT - reduced protein with condensed tannin treatment). IRS4 - Insulin receptor substrate 4; HPX - Hemopexin; LDH - L-lactate dehydrogenase; HK2 - Hexokinase 2; NG00_01909 - Acetyl-CoA carboxylase; PGK2 Phosphoglycerate kinase; RibProt - Ribosomal protein L14-like protein; Sulft Sulfotransferase; ALDH1 A3 - Aldehyde dehydrogenase 1; BLVRB - Biliverdin reductase B; COL11A1 - Collagen type XI alpha-1 chain; ECI1 - Enoyl-CoA delta isomerase; FF38_08888 - Putative apoptosis inhibitor 5; SIVA1 - SIVA1 apoptosis 
inducing factor. (For interpretation of the references to colour in this figure legend, the reader is referred to the web version of this article.)
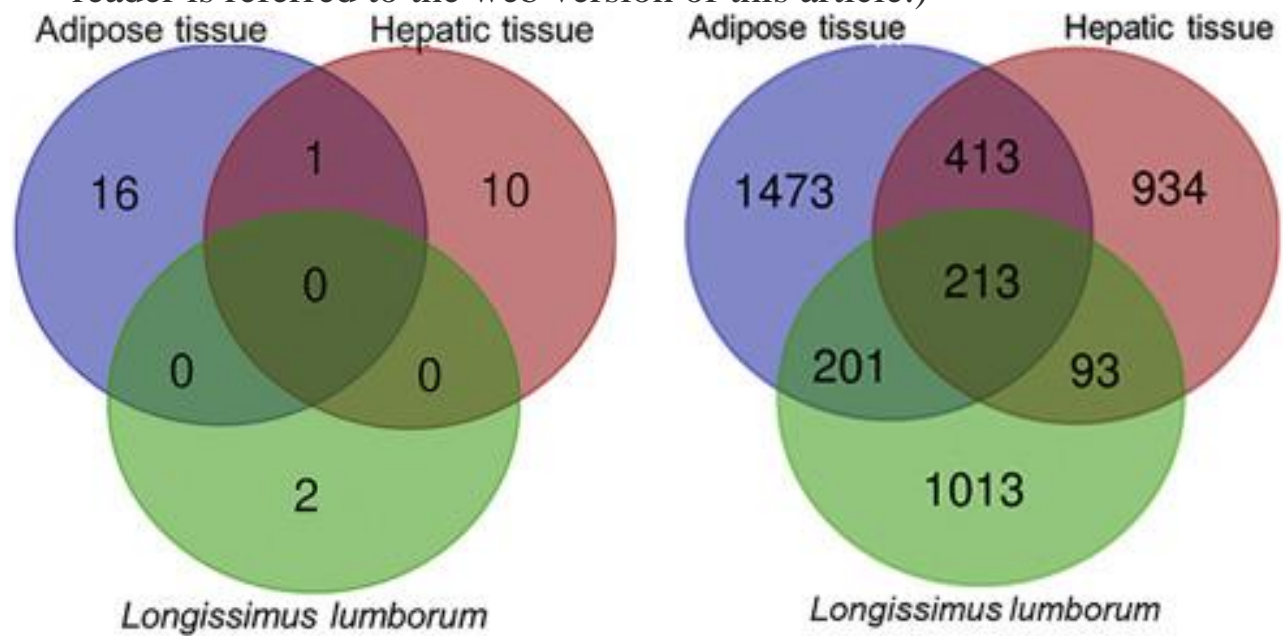

1. Download: Download high-res image (119KB)

2. Download : Download full-size image

Fig. 5. Venn diagram depicting the common and distinct protein identifications obtained in the muscle, hepatic and adipose tissues following gel-based (right panel) label-free (left panel) approaches.
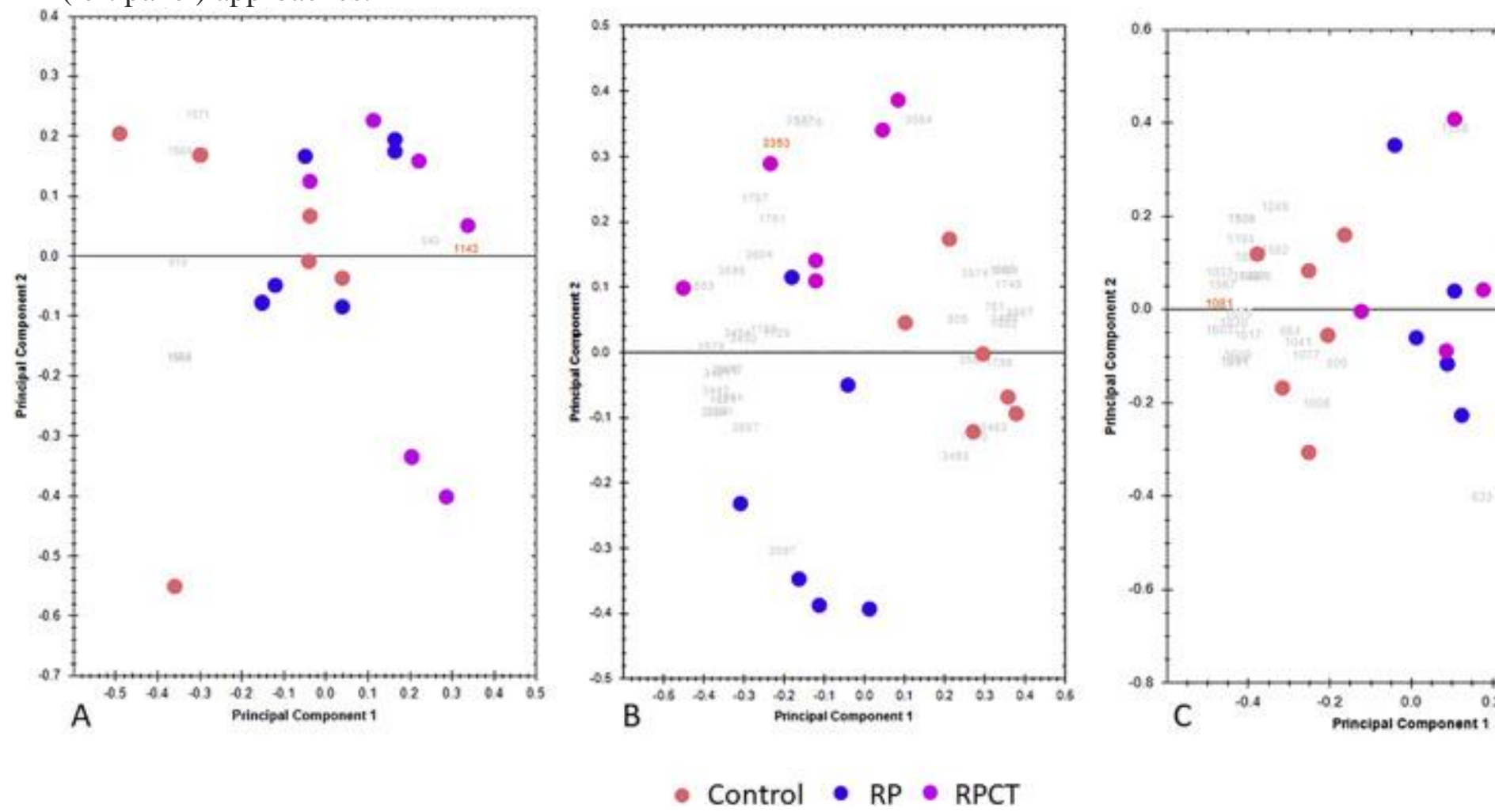

1. Download : Download high-res image (186KB) 
2. Download : Download full-size image

Fig. 6. Principal Component Analysis generated by the Samespots software, for each tissue. A - Muscle; B - Hepatic tissue; C - Adipose tissue. 

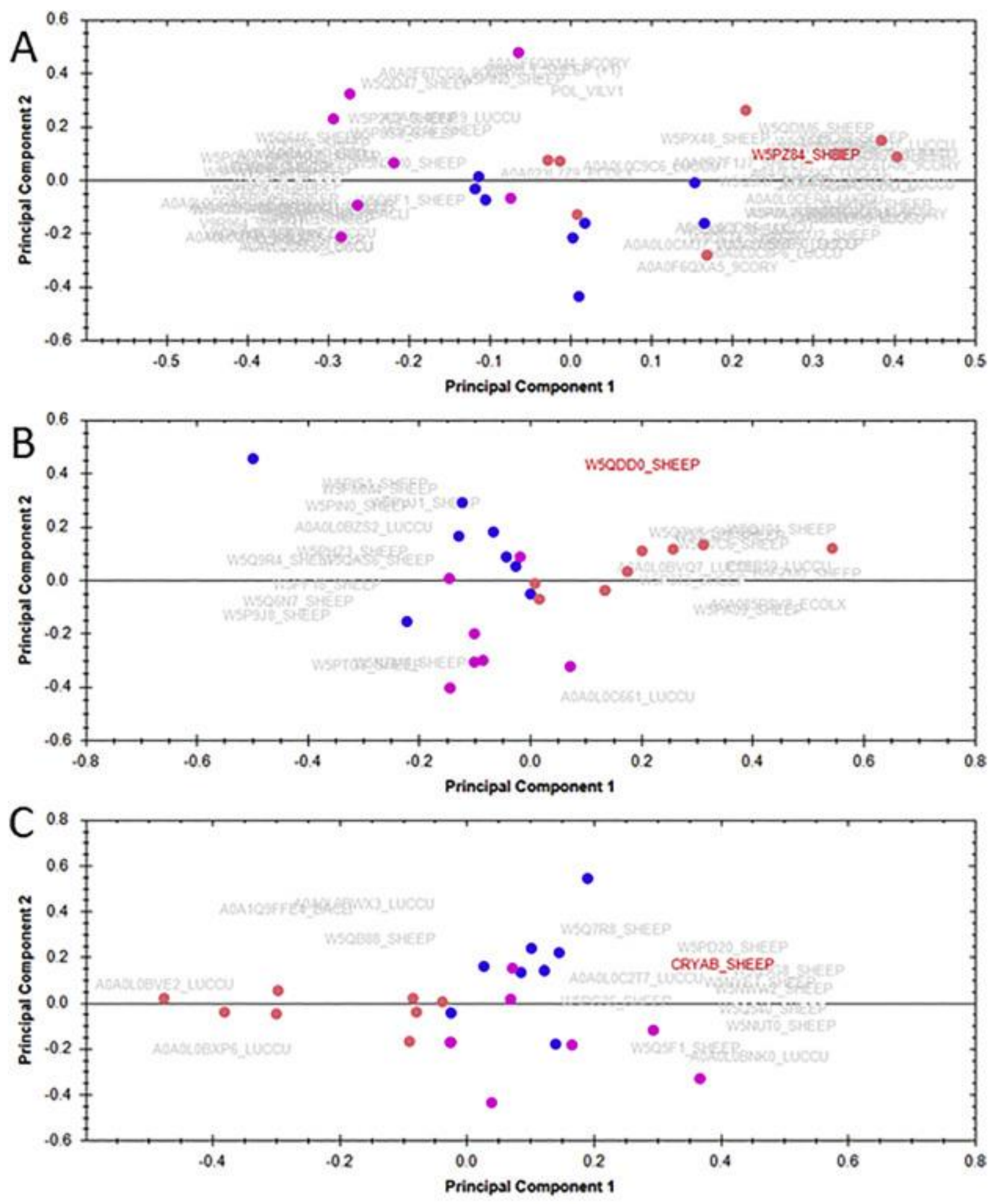

- Control • RP $\bullet \mathrm{RPCT}$

1. Download: Download high-res image (383KB)

2. Download: Download full-size image 
Fig. 7. Principal Component Analysis generated by the Progenesis software, for each tissue. A- Muscle; B - Hepatic tissue; C-Adipose tissue.

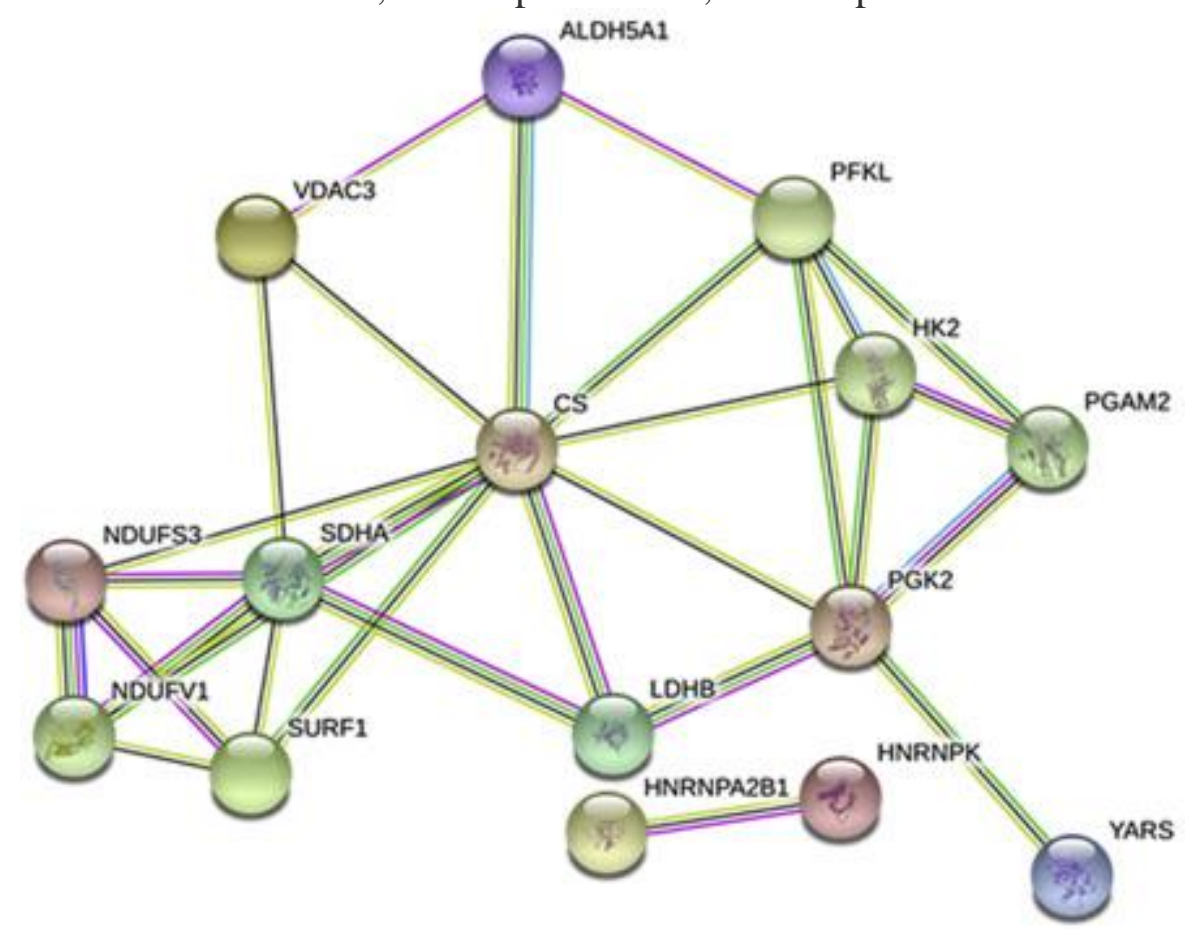

1. Download : Download high-res image (159KB)

2. Download : Download full-size image

Fig. 8. Protein-protein interaction for the muscle tissue obtained with STRING.

ALDH5A1 (Aldehyde dehydrogenase 5 family, member A1), PFKL (ATP-dependent 6phosphofructokinase), HK2 (Hexokinase 2), PGAM2 (Phosphoglycerate mutase 2), PGK2 (Phosphoglycerate kinase 2), YARS (Tyrosine-tRNA ligase), LDHB (Lactate dehydrogenase B), SDHA (Succinate dehydrogenase [ubiquinone] flavoprotein subunit), VDAC3 (Uncharacterized protein), HNRNPK (Heterogeneous nuclear ribonucleoprotein K), HNRNPA2B1 (Uncharacterized protein), NDUFV1 (NADH dehydrogenase [ubiquinone] flavoprotein 1), SURF1 (Uncharacterized protein), NDUFS3 (NADHubiquinone oxidoreductase core subunit S3), CS (Citrate synthase).

A separated description for proteins with differential abundance in the three tissues is presented in the following sections, also considering the different approaches.

\subsubsection{Gel-based approach}

A gel-based approach was carried out for all tissues involved in this study. Representative gels for each tissues are depicted in Fig. 9. Proteins with differential abundance in the muscle, hepatic and adipose tissues are listed in Table 1, Table 2- 
, Table 3, respectively. Most proteins were uniquely identified in these tissues, as seen in Fig. 5. The reports output by the SameSpots software are provided for each tissue in supplementary files 2, 3 and 4 for the muscle, hepatic and adipose tissue; respectively.

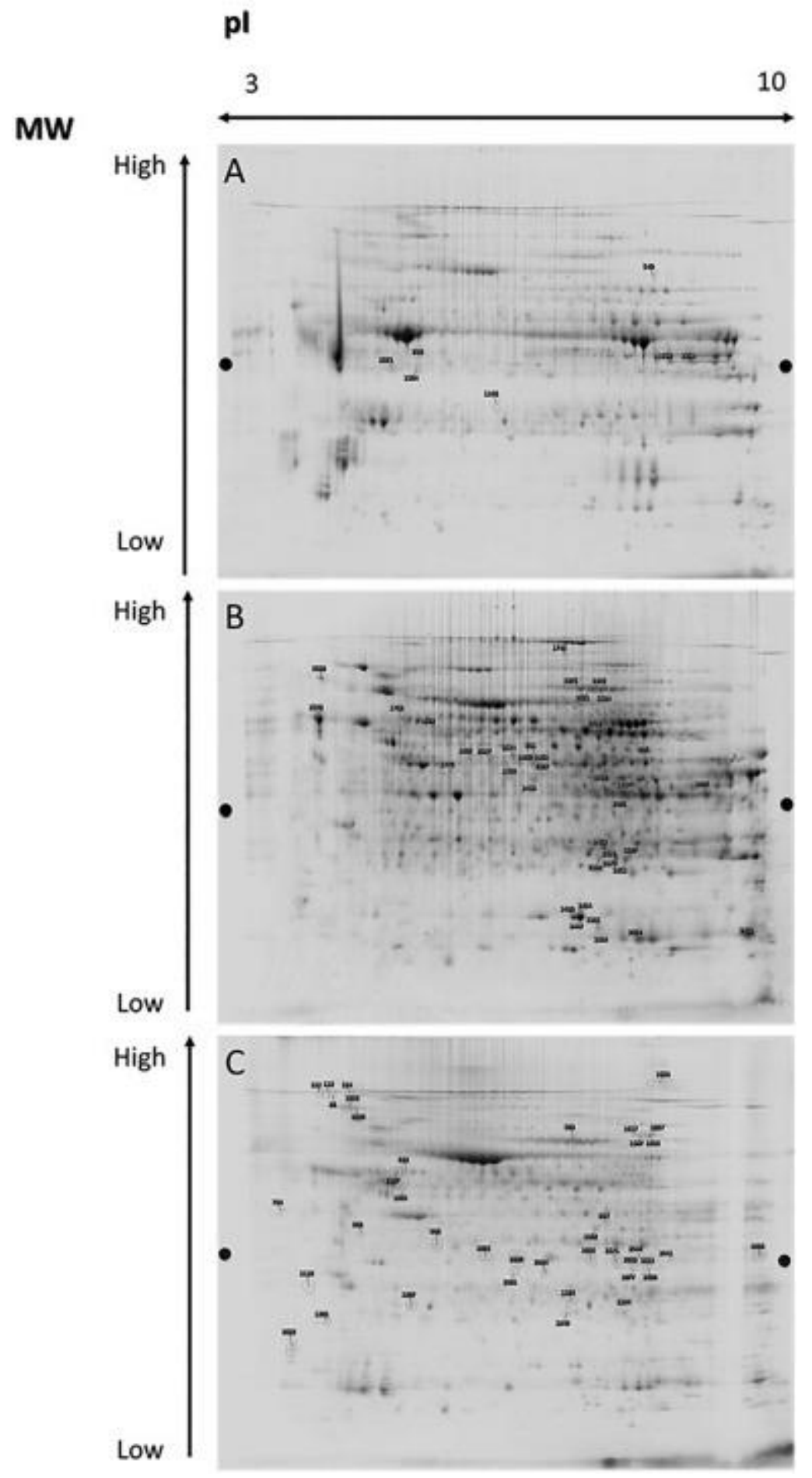




\section{Download : Download high-res image (220KB)}

2. Download: Download full-size image

Fig. 9. Representative gels that resulted from 2D-DIGE analysis. Molecular weight (MW) and isoelectric point (pI) scales are provided. A- longissimus lumborum muscle, Bhepatic tissue, $\mathrm{C}$ - adipose tissue.

Table 1. Identified proteins in the muscle tissue (longissimus lumborum) with differential abundance following the gel-based approach. Ctrl - Control; RP - Reduced Protein (12\% $\mathrm{CP}) ; \mathrm{RPCP}-12 \% \mathrm{CP}$ with CT treatment.

\begin{tabular}{|c|c|c|c|c|c|c|c|c|c|}
\hline $\begin{array}{c}\text { Spot } \\
\text { Number }\end{array}$ & $\begin{array}{l}\text { Protein } \\
\text { Accession }\end{array}$ & Protein Description & $\begin{array}{l}\text { Gene } \\
\text { Name }\end{array}$ & $\begin{array}{c}\text { Anova } \\
\text { (p) }\end{array}$ & $\begin{array}{l}\text { Max } \\
\text { Fold }\end{array}$ & $\begin{array}{l}\text { Protein } \\
\text { Score } *\end{array}$ & Avera & $\begin{array}{l}\text { ge Norr } \\
\text { Volume }\end{array}$ & alised \\
\hline & & & & & & & Ctrl & $\mathbf{R P}$ & RPCT \\
\hline 1143 & W5PVY5_SHEEP & $\begin{array}{l}\text { Phosphoglycerate } \\
\text { mutase OS=Ovis } \\
\text { aries OX = 9940 } \\
\mathrm{GN}=\mathrm{PGAM} 2 \mathrm{PE}=3 \mathrm{SV}=1\end{array}$ & PGAM2 & 0.036 & 1.3 & 65 & 0.673 & 0.892 & 0.901 \\
\hline 1571 & B2LU28_SHEEP & $\begin{array}{l}\text { TPM1 OS=Ovis } \\
\text { aries } \mathrm{OX}=9940 \mathrm{PE}=2 \\
\mathrm{SV}=1\end{array}$ & TPM1 & 0.047 & 1.8 & 838 & 1.858 & 1.444 & 1.028 \\
\hline
\end{tabular}

Proteins Score was considered significant when higher than $61(p<.05)$.

Table 2-. Identified proteins in the hepatic tissue with differential abundance following the gel-based approach. Ctrl - Control; RP - Reduced Protein (12\% CP); RPCT - 12\% CP with CT treatment.

$\begin{gathered}\text { Spot } \\ \text { Number }\end{gathered} \quad \begin{gathered}\text { Protein } \\ \text { Accession }\end{gathered}$




\begin{tabular}{|c|c|c|c|c|c|c|c|c|c|}
\hline \multirow[t]{2}{*}{$\begin{array}{l}\text { Spot } \\
\text { Number }\end{array}$} & \multirow[t]{2}{*}{$\begin{array}{l}\text { Protein } \\
\text { Accession }\end{array}$} & \multirow[t]{2}{*}{ Protein Description } & \multirow[t]{2}{*}{ Gene Name } & \multirow[t]{2}{*}{$\begin{array}{c}\text { Anova } \\
\text { (p) }\end{array}$} & \multirow[t]{2}{*}{$\begin{array}{l}\text { Max } \\
\text { Fold }\end{array}$} & \multirow[t]{2}{*}{$\begin{array}{l}\text { Protein } \\
\text { Score } \underline{x}\end{array}$} & \multicolumn{3}{|c|}{$\begin{array}{c}\text { Average Normalised } \\
\text { Volumes }\end{array}$} \\
\hline & & & & & & & Ctrl & $\mathbf{R P}$ & RPCT \\
\hline 3375 & W5PF65_SHEEP & $\begin{array}{l}\text { Transferrin OS=Ovis } \\
\text { aries } \mathrm{OX}=9940 \mathrm{GN}=\mathrm{TF} \\
\mathrm{PE}=3 \mathrm{SV}=1\end{array}$ & TF & 0.007 & 2 & 734 & 0.488 & 0.971 & 0.999 \\
\hline 3384 & W5PF65_SHEEP & $\begin{array}{l}\text { Transferrin OS=Ovis } \\
\text { aries OX = 9940 GN = TF } \\
\mathrm{PE}=3 \mathrm{SV}=1\end{array}$ & TF & 0.010 & 2 & 710 & 0.585 & 1.178 & 1.033 \\
\hline 3576 & NP_776676.1 & $\begin{array}{l}\text { flavin reductase (NADPH) } \\
\text { [Bos taurus] }\end{array}$ & BLVRB & 0.012 & 2.8 & 224 & 0.786 & 0.982 & 2.204 \\
\hline 3458 & W5PGC5_SHEEP & $\begin{array}{l}\text { Aldose 1-epimerase OS=Ovis } \\
\text { aries OX = 9940 GN = GALM } \\
\mathrm{PE}=3 \mathrm{SV}=1\end{array}$ & GALM & 0.013 & 1.3 & 459 & 1.065 & 1.031 & 0.844 \\
\hline 3454 & SODC_SHEEP & $\begin{array}{l}\text { Superoxide dismutase }[\mathrm{Cu} \\
\mathrm{Zn} \text { ] OS=Ovis aries } \mathrm{OX}=9940 \\
\mathrm{GN}=\mathrm{SOD} 1 \mathrm{PE}=1 \mathrm{SV}=2\end{array}$ & SOD1 & 0.013 & 2.5 & 941 & 0.688 & 1.384 & 1.691 \\
\hline 3578 & W5PJG7_SHEEP & $\begin{array}{l}\text { Calreticulin OS=Ovis } \\
\text { aries } \mathrm{OX}=9940 \mathrm{GN}=\mathrm{CALR} \\
\mathrm{PE}=3 \mathrm{SV}=1\end{array}$ & CALR & 0.014 & 1.5 & 960 & 0.756 & 1.119 & 1.087 \\
\hline & & Biliverdin reductase $B$ & & & & & & & \\
\hline 3597 & W5P9J8_SHEEP & $\begin{array}{l}\text { OS }=\text { Ovis aries OX }=9940 \\
\mathrm{GN}=\mathrm{BLVRB} \mathrm{PE}=4 \mathrm{SV}=1\end{array}$ & BLVRB & 0.022 & 1.8 & 82 & 0.986 & 1.789 & 1.07 \\
\hline 3607 & W5PN69_SHEEP & $\begin{array}{l}\text { PREDICTED: dihydrodiol } \\
\text { dehydrogenase } 3 \text { [Ovis aries] }\end{array}$ & LOC101109111 & 0.026 & 2 & 1110 & 0.719 & 1.413 & 0.935 \\
\hline 3443 & W5PF65_SHEEP & $\begin{array}{l}\text { Transferrin OS=Ovis } \\
\text { aries OX }=9940 \mathrm{GN}=\mathrm{TF} \\
\mathrm{PE}=3 \mathrm{SV}=1\end{array}$ & TF & 0.030 & 1.8 & 1060 & 0.59 & 1.063 & 0.999 \\
\hline 3430 & SODC_SHEEP & $\begin{array}{l}\text { Superoxide dismutase }[\mathrm{Cu} \\
\mathrm{Zn} \text { ] OS=Ovis aries } \mathrm{OX}=9940 \\
\mathrm{GN}=\mathrm{SOD} 1 \mathrm{PE}=1 \mathrm{SV}=2\end{array}$ & SOD1 & 0.036 & 1.8 & 1130 & 0.706 & 1.161 & 1.246 \\
\hline
\end{tabular}




\begin{tabular}{|c|c|c|c|c|c|c|c|c|c|}
\hline \multirow[t]{2}{*}{$\begin{array}{c}\text { Spot } \\
\text { Number }\end{array}$} & \multirow[t]{2}{*}{$\begin{array}{c}\text { Protein } \\
\text { Accession }\end{array}$} & \multirow[t]{2}{*}{ Protein Description } & \multirow[t]{2}{*}{ Gene Name } & \multirow[t]{2}{*}{$\begin{array}{c}\text { Anova } \\
\text { (p) }\end{array}$} & \multirow[t]{2}{*}{$\begin{array}{l}\text { Max } \\
\text { Fold }\end{array}$} & \multirow[t]{2}{*}{$\begin{array}{l}\text { Protein } \\
\text { Score } \underline{*}\end{array}$} & \multicolumn{3}{|c|}{$\begin{array}{c}\text { Average Normalised } \\
\text { Volumes }\end{array}$} \\
\hline & & & & & & & Ctrl & $\mathbf{R P}$ & RPCT \\
\hline 761 & W5PHX1_SHEEP & $\begin{array}{l}\text { Adenosylhomocysteinase } \\
\text { OS=Ovis aries OX = 9940 } \\
\text { GN }=\text { LOC } 101112245 \mathrm{PE}=3 \\
\mathrm{SV}=1\end{array}$ & LOC101112245 & 0.040 & 1.5 & 683 & 1.350 & 0.944 & 0.922 \\
\hline 3574 & W5PHX1_SHEEP & $\begin{array}{l}\text { Adenosylhomocysteinase } \\
\text { OS=Ovis aries OX = 9940 } \\
\text { GN = LOC101112245 PE = } 3 \\
\text { SV = } 1\end{array}$ & LOC101112245 & 0.045 & 1.5 & 772 & 1.219 & 0.827 & 0.886 \\
\hline 3604 & Q1KYZ8_OVIMU & $\begin{array}{l}\text { Beta globin chain OS=Ovis } \\
\text { aries musimon } \mathrm{OX}=9938 \\
\mathrm{GN}=\mathrm{HBB} \mathrm{PE}=3 \mathrm{SV}=1\end{array}$ & $\mathrm{HBB}$ & 0.045 & 1.7 & 919 & 0.758 & 1.307 & 1.287 \\
\hline & & Argininosuccinate synthase 1 & & & & & & & \\
\hline 805 & W5PCU1_SHEEP & $\begin{array}{l}\text { OS=Ovis aries OX }=9940 \\
\mathrm{GN}=\mathrm{ASS} 1 \mathrm{PE}=3 \mathrm{SV}=1\end{array}$ & ASS1 & 0.048 & 1.5 & 861 & 1.297 & 0.965 & 0.838 \\
\hline
\end{tabular}

Proteins Score was considered significant when higher than $61(\mathrm{p}<.05)$.

Table 3. Identified proteins in the adipose tissue with differential abundance following the gel-based approach. Ctrl - Control; RP - Reduced Protein (12\% CP); RPCP - 12\% CP with CT treatment.

\begin{tabular}{|c|c|c|c|c|c|c|c|c|c|}
\hline \multirow[t]{2}{*}{$\begin{array}{c}\text { Spot } \\
\text { Number }\end{array}$} & \multirow[t]{2}{*}{$\begin{array}{l}\text { Protein } \\
\text { Accession }\end{array}$} & \multirow[t]{2}{*}{ Protein Description } & \multirow[t]{2}{*}{ Gene Name } & \multirow[t]{2}{*}{$\begin{array}{c}\text { Anova } \\
\text { (p) }\end{array}$} & \multirow[t]{2}{*}{$\begin{array}{l}\text { Max } \\
\text { Fold }\end{array}$} & \multirow[t]{2}{*}{$\begin{array}{l}\text { Protein } \\
\text { Score } \text { 米 }\end{array}$} & \multicolumn{3}{|c|}{$\begin{array}{c}\text { Average Normalised } \\
\text { Volumes }\end{array}$} \\
\hline & & & & & & & Ctrl & $\mathbf{R P}$ & RPCT \\
\hline 1081 & W5P772_SHEEP & $\begin{array}{l}\text { Enoyl-CoA hydratase } \\
1 \mathrm{OS}=\text { Ovis } \\
\text { aries } \mathrm{OX}=9940 \\
\mathrm{GN}=\mathrm{ECH} 1 \mathrm{PE}=3 \\
\mathrm{SV}=1\end{array}$ & ECH1 & 0.001 & 1.3 & 772 & 1.186 & 0.921 & 0.925 \\
\hline 1567 & W5QAA9_SHEEP & $\begin{array}{l}\text { Aconitate hydratase, } \\
\text { mitochondrial } \\
\text { OS=Ovis }\end{array}$ & $\mathrm{ACO} 2$ & 0.004 & 1.4 & 573 & 1.03 & 0.742 & 0.763 \\
\hline
\end{tabular}




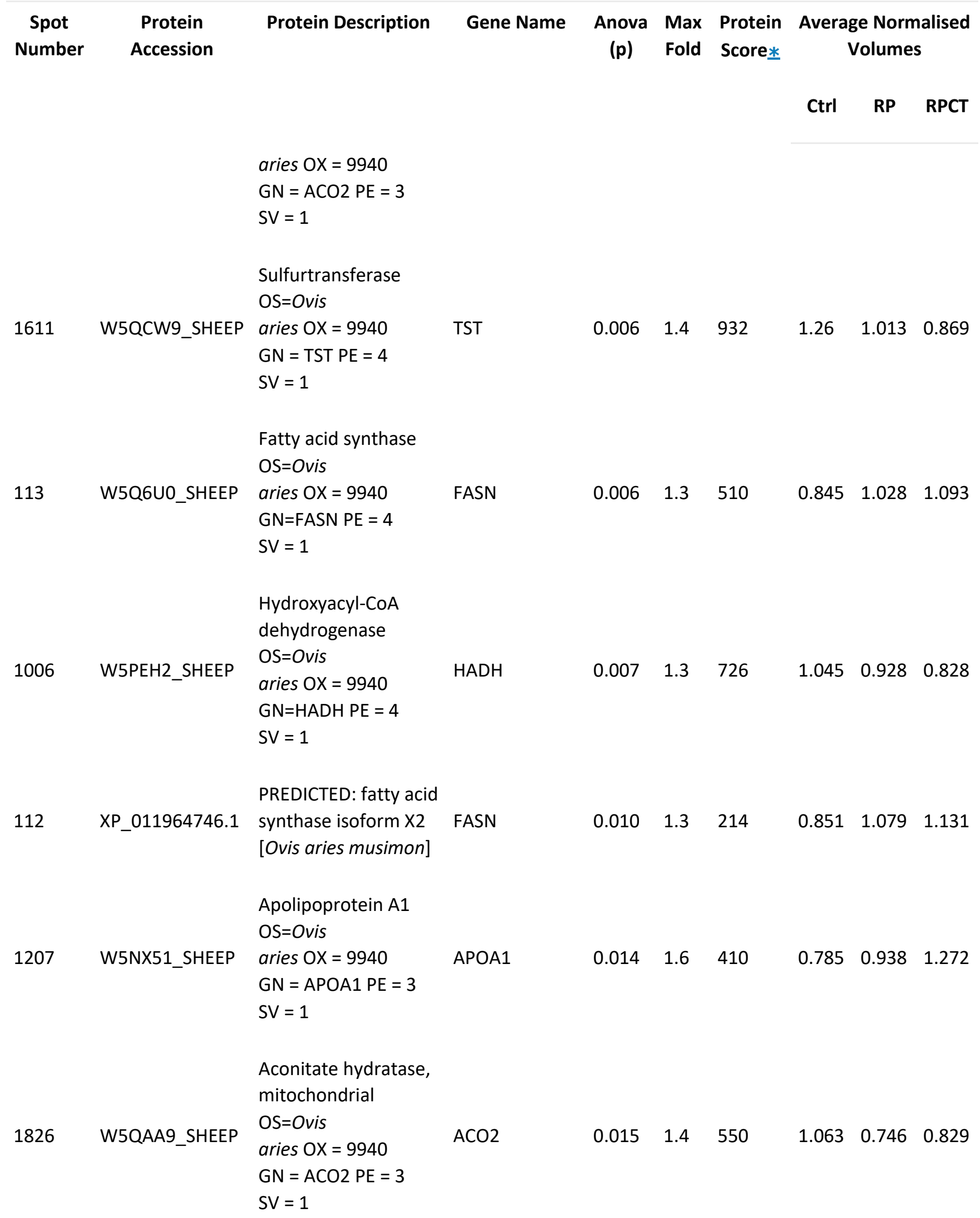




\begin{tabular}{|c|c|c|c|c|c|c|c|c|c|}
\hline \multirow[t]{2}{*}{$\begin{array}{l}\text { Spot } \\
\text { Number }\end{array}$} & \multirow[t]{2}{*}{$\begin{array}{l}\text { Protein } \\
\text { Accession }\end{array}$} & \multirow[t]{2}{*}{ Protein Description } & \multirow[t]{2}{*}{ Gene Name } & \multirow[t]{2}{*}{$\begin{array}{c}\text { Anova } \\
\text { (p) }\end{array}$} & \multirow[t]{2}{*}{$\begin{array}{l}\text { Max } \\
\text { Fold }\end{array}$} & \multirow[t]{2}{*}{$\begin{array}{l}\text { Protein } \\
\text { Score娄 }\end{array}$} & \multicolumn{3}{|c|}{$\begin{array}{c}\text { Average Normalised } \\
\text { Volumes }\end{array}$} \\
\hline & & & & & & & Ctrl & $\mathbf{R P}$ & RPCT \\
\hline 903 & W5NUT0_SHEEP & $\begin{array}{l}\text { Caveolae associated } \\
\text { protein } 1 \mathrm{OS}=\text { Ovis } \\
\text { aries } \mathrm{OX}=9940 \\
\mathrm{GN}=\mathrm{CAVIN} 1 \mathrm{PE}=4 \\
\mathrm{SV}=1\end{array}$ & CAVIN1 & 0.021 & 1.4 & 103 & 0.814 & 0.997 & 1.178 \\
\hline & & $\begin{array}{l}\text { Microfibril associated } \\
\text { protein } 5 \text { OS=Ovis }\end{array}$ & & & & & & & \\
\hline 1119 & W5NV70_SHEEP & $\begin{array}{l}\text { aries } \mathrm{OX}=9940 \\
\mathrm{GN}=\mathrm{MFAP} 5 \mathrm{PE}=4 \\
\mathrm{SV}=1\end{array}$ & MFAP5 & 0.021 & 1.3 & 133 & 1.094 & 1.366 & 1.455 \\
\hline & & $\begin{array}{l}\text { Enoyl-CoA hydratase } \\
1 \text { OS=Ovis }\end{array}$ & & & & & & & \\
\hline 1084 & W5P772_SHEEP & $\begin{array}{l}\text { aries } \mathrm{OX}=9940 \\
\mathrm{GN}=\mathrm{ECH} 1 \mathrm{PE}=3 \\
\mathrm{SV}=1\end{array}$ & $\mathrm{ECH} 1$ & 0.023 & 1.3 & 956 & 1.314 & 1.024 & 0.985 \\
\hline & & $\begin{array}{l}\text { Actin, cytoplasmic } 1 \\
\text { OS=Ovis }\end{array}$ & & & & & & & \\
\hline 794 & ACTB_SHEEP & $\begin{array}{l}\text { aries } \mathrm{OX}=9940 \\
\mathrm{GN}=\mathrm{ACTB} \mathrm{PE}=2 \\
\mathrm{SV}=1\end{array}$ & АСТВ & 0.023 & 1.4 & 505 & 1.668 & 2.411 & 2.318 \\
\hline 1281 & W5PHI8_SHEEP & $\begin{array}{l}\text { Dermatopontin } \\
\text { OS=Ovis } \\
\text { aries OX }=9940 \\
\text { GN }=\text { DPT PE = } 4 \\
\text { SV }=1\end{array}$ & DPT & 0.025 & 1.4 & 276 & 0.869 & 1.15 & 1.244 \\
\hline 1044 & W5PSZ5_SHEEP & $\begin{array}{l}\text { Annexin OS=Ovis } \\
\text { aries OX }=9940 \\
\text { GN }=\text { ANXA1 PE = } 3 \\
\text { SV }=1\end{array}$ & ANXA1 & 0.026 & 1.5 & 1230 & 1.31 & 0.914 & 0.85 \\
\hline 1690 & W5PHI7_SHEEP & $\begin{array}{l}\text { PREDICTED: serpin } \\
\text { A3-1-like [Ovis aries] }\end{array}$ & LOC101116892 & 0.029 & 1.6 & 435 & 0.751 & 1.196 & 1.183 \\
\hline 633 & W5Q1L2_SHEEP & $\begin{array}{l}\text { Heat shock protein } \\
\text { family D (Hsp60) }\end{array}$ & HSPD1 & 0.048 & 1.2 & 627 & 0.924 & 1.133 & 0.918 \\
\hline
\end{tabular}




\begin{tabular}{|c|c|c|c|c|c|c|c|c|c|}
\hline \multirow[t]{2}{*}{$\begin{array}{c}\text { Spot } \\
\text { Number }\end{array}$} & \multirow[t]{2}{*}{$\begin{array}{l}\text { Protein } \\
\text { Accession }\end{array}$} & Protein Description & \multirow[t]{2}{*}{ Gene Name } & \multirow[t]{2}{*}{$\begin{array}{c}\text { Anova } \\
\text { (p) }\end{array}$} & \multirow[t]{2}{*}{$\begin{array}{l}\text { Max } \\
\text { Fold }\end{array}$} & \multirow[t]{2}{*}{$\begin{array}{l}\text { Protein } \\
\text { Score米 }\end{array}$} & \multicolumn{3}{|c|}{$\begin{array}{c}\text { Average Normalised } \\
\text { Volumes }\end{array}$} \\
\hline & & $\begin{array}{l}\text { member } 1 \text { OS=Ovis } \\
\text { aries OX }=9940 \\
\text { GN=HSPD1 PE = } 3 \\
\text { SV }=1\end{array}$ & & & & & Ctrl & RP & RPCT \\
\hline 509 & W5PF65_SHEEP & $\begin{array}{l}\text { Transferrin OS=Ovis } \\
\text { aries OX = 9940 } \\
\text { GN = TF PE = 3 SV = } 1\end{array}$ & TF & 0.049 & 1.3 & 773 & 1.134 & 0.904 & 1.035 \\
\hline 1622 & XP_012365654.1 & $\begin{array}{l}\text { PREDICTED: keratin, } \\
\text { type II cytoskeletal } 2 \\
\text { epidermal isoform X3 } \\
\text { [Nomascus } \\
\text { leucogenys] }\end{array}$ & LOC100596772 & 0.056 & 1.7 & 142 & 1.317 & 2.287 & 2.018 \\
\hline 1617 & W5QAA9_SHEEP & $\begin{array}{l}\text { Aconitate hydratase, } \\
\text { mitochondrial } \\
\text { OS=Ovis } \\
\text { aries OX = 9940 } \\
\text { GN = ACO2 PE = } 3 \\
\text { SV = } 1\end{array}$ & $\mathrm{ACO} 2$ & 0.093 & 1.2 & 392 & 0.976 & 0.819 & 0.804 \\
\hline 1558 & W5P813_SHEEP & $\begin{array}{l}\text { Collagen type IV } \\
\text { alpha } 1 \text { chain } \\
\text { OS=Ovis } \\
\text { aries OX = 9940 } \\
\text { GN=COL4A1 PE = 4 } \\
\text { SV }=1\end{array}$ & COL4A1 & 0.160 & 1.2 & 397 & 1.057 & 1.131 & 1.267 \\
\hline
\end{tabular}

$*$

Proteins Score was considered significant when higher than $61(\mathrm{p}<.05)$.

3.2.1.1. Longissimus lumborum muscle tissue

The longissimus lumborum (LL) muscle had two proteins successfully identified with differential abundance. Phosphoglycerate mutase was abundant in the muscle tissue of lambs fed reduced protein diets (RPCT and RP) whereas tropomyosin 1 (TPM1) had higher abundance in the muscle tissue of control lambs. 


\subsubsection{Hepatic tissue}

Sixteen proteins were identified with differential abundance in the hepatic tissue, most of them related to catalytic activity. Four transferrin spots were identified with lower abundance in the control group in comparison to the other two. The opposite was verified in two spots identified as adenosylhomocysteinase. Two spots of flavin reductase (NADPH) and superoxide dismutase were two proteins identified in higher abundance only in lambs fed reduced protein with CT treatment. Biliverdin reductase $\mathrm{B}$ and dihydrodiol dehydrogenase 3 were two proteins identified with high abundance in lambs fed untreated reduced protein diets.

\subsubsection{Adipose tissue}

The perirenal fat gel-based analysis resulted in the single identification of 20 proteins with differential abundance between experimental groups. Most of them were equally divided (33.3\%) between catalytic and binding activities whilst most belong to cellular process $(53.3 \%)$. The control treatment had lower abundance of proteins related to adipogenesis such as fatty acid synthase and higher abundance of enoylCoA hydratase, a fatty acid oxidizing enzyme, than the two other treatments. Lambs fed with untreated $12 \% \mathrm{CP}$ had high abundance of heat shock proteins (HSP). Control treatment had lower abundance of proteins such as fatty acid synthase (vs both groups) and apolipoprotein A1 (vs RPCT).

\subsubsection{Label-free approach}

The label-free approach resulted in the identification of a large number of proteins per tissue, which are listed in supplementary files 5, 6 and 7 for the muscle, hepatic and adipose tissues, respectively. In Fig. 10, heatmaps for differential abundant proteins of each comparison is provided. Similarly to what is presented in the Principal Component Analysis there is lack of a clear clustering pattern in protein abundance for each comparison. Lists of differentially abundant proteins identified via the labelfree approach are provided in Table 4, Table 5, Table 6 for the muscle, hepatic and adipose tissues, respectively. Two groups were compared at a time regarding differential protein abundance. 

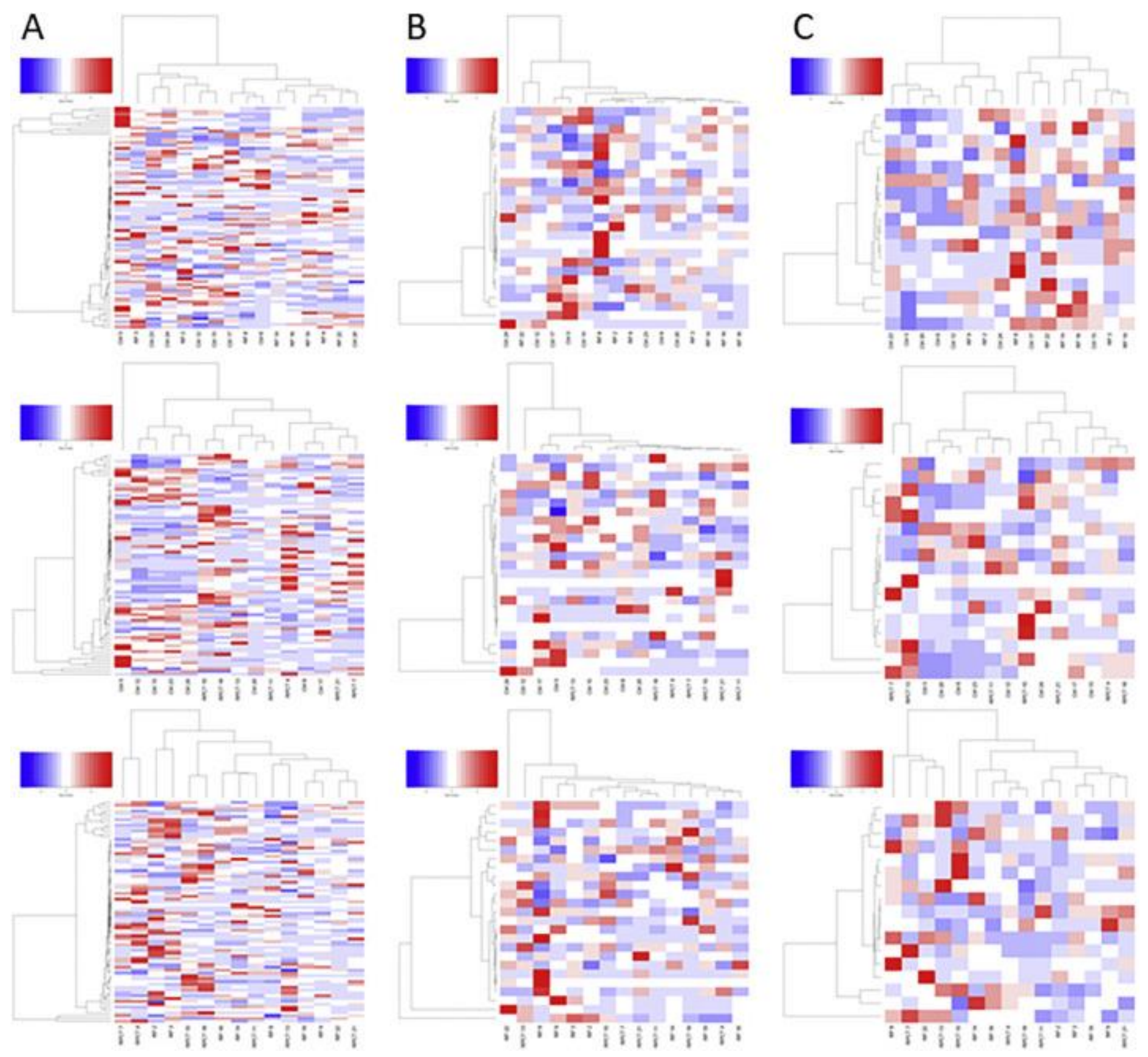

1. Download : Download high-res image (531KB)

2. Download: Download full-size image

Fig. 10. Heatmaps obtained for the normalised data of differentially abundant proteins identified with label-free approach. A- Muscle tissue, B- Hepatic tissue, C- Adipose tissue. Lines, from top to bottom depict different comparisons: Control vs RP, Control vs RPCT, RP vs RPCT. Lines represent different proteins and columns are different replicates. Red indicates higher abundance, whereas blue indicates lower abundance. (For 
interpretation of the references to colour in this figure legend, the reader is referred to the web version of this article.)

Table 4. Significant identified proteins with differential abundance following the labelfree approach for the muscle (longissimus lumborum) tissue. Ctrl - Control; RP Reduced Protein; RPCT - Reduced protein with CT treatment.

Accession

Protein description

$\begin{array}{cccc}\text { Peptide } & \text { Unique } & \text { Anova } & \text { Fold } \\ \text { count } & \text { peptides } & \text { (p) } & \text { change }\end{array}$

Ctrl vs RP

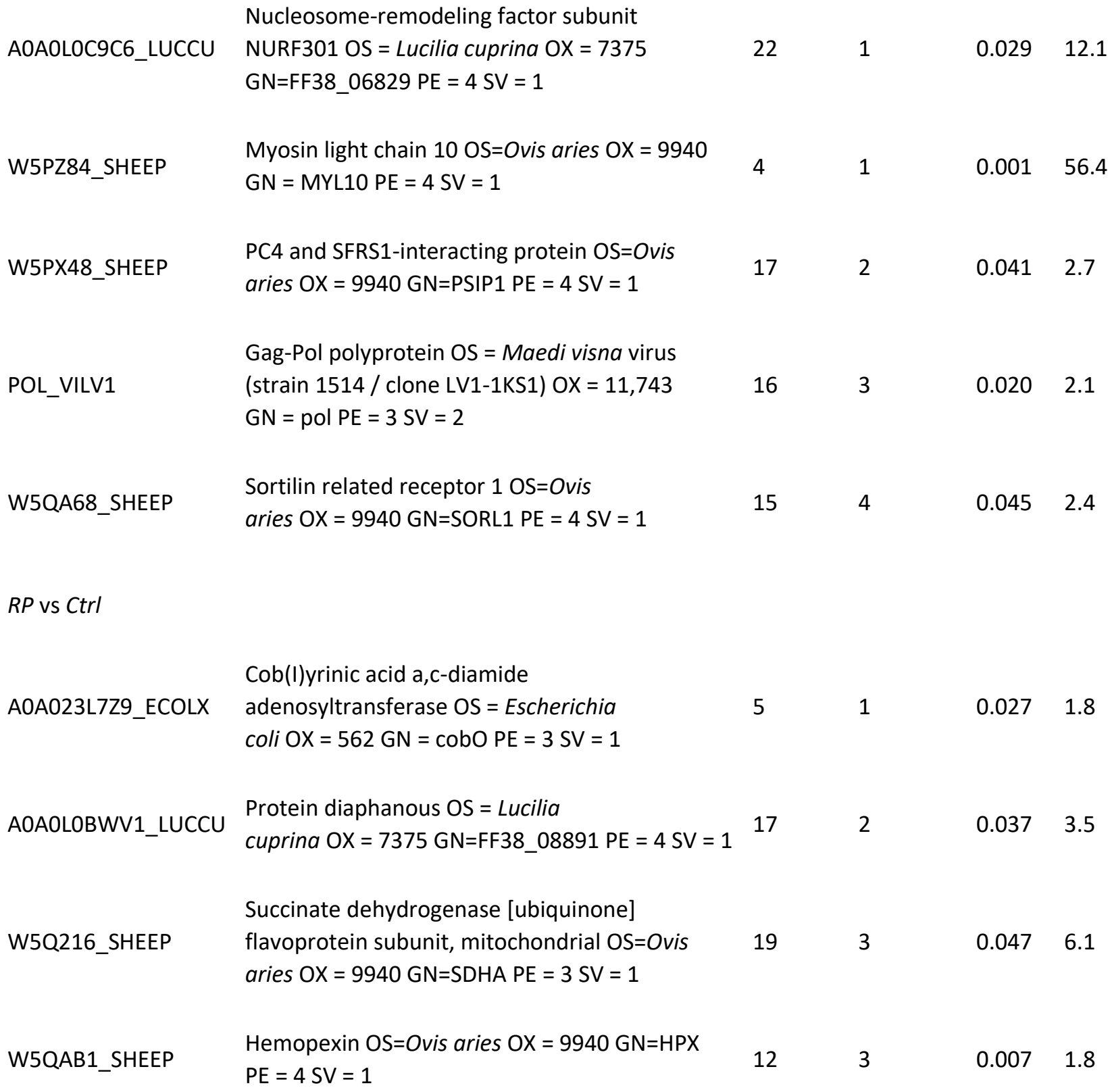


Accession

Protein description
Peptide Unique

count peptides
Anova Fold

(p) change

Ctrl vs RPCT

W5Q6F0_SHEEP

Histone $\mathrm{H} 2 \mathrm{~A}$ OS=Ovis aries $\mathrm{OX}=9940 \mathrm{GN}=\mathrm{H} 2 \mathrm{AFX}$

$\mathrm{PE}=3 \mathrm{SV}=1$

1

0.030

1.6

W5PC69_SHEEP

Uncharacterized protein OS=Ovis

aries $\mathrm{OX}=9940 \mathrm{PE}=4 \mathrm{SV}=1$

8

1

$0.026 \quad 116.6$

W5P2W5_SHEEP

Chromosome $X$ open reading frame 36 OS=Ovis

aries $\mathrm{OX}=9940 \mathrm{GN}=\mathrm{CXorf36} \mathrm{PE}=4 \mathrm{SV}=1$

6

1

$0.008 \quad 5.2$

Phosphoenolpyruvate carboxykinase (ATP)

A0A1Q9FXV3_BACLI

$\mathrm{OS}=$ Bacillus licheniformis $\mathrm{OX}=1402 \mathrm{GN}=$ pckA

10

$\mathrm{PE}=3 \mathrm{SV}=1$

1

$0.004 \quad 53.4$

AOAOLOCBPO_LUCCU

Uncharacterized protein OS = Lucilia

cuprina $\mathrm{OX}=7375 \mathrm{GN}=\mathrm{FF} 38 \_08681 \mathrm{PE}=3 \mathrm{SV}=1$

22

1

$0.011 \quad 1.7$

Pseudopodium enriched atypical kinase 1

W5NUJ2_SHEEP

OS=Ovis aries OX $=9940 \mathrm{GN}=\mathrm{PEAK} 1 \mathrm{PE}=4$

18

1

$0.029 \quad 28.8$

$\mathrm{SV}=1$

W5Q6J4_SHEEP

Keratin 84 OS=Ovis aries OX $=9940$ GN=KRT84

$\mathrm{PE}=3 \mathrm{SV}=1$

11

1

$0.023 \quad 1.6$

W5QDM6_SHEEP

Striatin interacting protein $1 \mathrm{OS}=\mathrm{Ovis}$

aries $\mathrm{OX}=9940 \mathrm{GN}=\mathrm{STRIP} 1 \mathrm{PE}=4 \mathrm{SV}=1$

15

1

$0.041 \quad 3.6$

AOAOLOCER4_LUCCU

Pickpocket protein 19 OS = Lucilia

cuprina $\mathrm{OX}=7375 \mathrm{GN}=\mathrm{FF} 38 \_11673 \mathrm{PE}=3 \mathrm{SV}=1$

1

$0.016 \quad 3.4$

AOAOLOCJD1_LUCCU

Uncharacterized protein OS = Lucilia

cuprina $\mathrm{OX}=7375 \mathrm{GN}=\mathrm{FF} 38 \_11124 \mathrm{PE}=3 \mathrm{SV}=16$

1

$0.008 \quad 2.7$

Transcriptional accessory protein

A0A0F6QXA5_9CORY

OS=Corynebacterium

camporealensis OX = 161,896 GN=UL81_07400

29

2

$0.048 \quad 7.8$

$\mathrm{PE}=4 \mathrm{SV}=1$

W5NTF0_SHEEP

Centromere protein I OS=Ovis aries OX $=9940$

$\mathrm{GN}=\mathrm{CENPI} \mathrm{PE}=4 \mathrm{SV}=1$

2

0.024

13.8 


\begin{tabular}{|c|c|c|c|c|c|}
\hline Accession & Protein description & $\begin{array}{l}\text { Peptide } \\
\text { count }\end{array}$ & $\begin{array}{l}\text { Unique } \\
\text { peptides }\end{array}$ & $\begin{array}{l}\text { Anova } \\
\text { (p) }\end{array}$ & $\begin{array}{l}\text { Fold } \\
\text { change }\end{array}$ \\
\hline A0A126QYU6_9EURY & $\begin{array}{l}\text { Helicase OS = methanogenic archaeon mixed } \\
\text { culture ISO4-G1 OX = 1,452,364 } \\
\text { GN = AUP07_1512 PE = 4 SV = } 1\end{array}$ & 15 & 2 & 0.005 & 4.0 \\
\hline AOAOLOCBR9_LUCCU & $\begin{array}{l}\text { Uncharacterized protein OS = Lucilia } \\
\text { cuprina } \mathrm{OX}=7375 \mathrm{GN}=\mathrm{FF} 38 \_05064 \mathrm{PE}=4 \mathrm{SV}=1\end{array}$ & 20 & 3 & 0.050 & 10.7 \\
\hline W5NZW7_SHEEP & $\begin{array}{l}\text { Uncharacterized protein OS=Ovis } \\
\text { aries } \mathrm{OX}=9940 \mathrm{PE}=4 \mathrm{SV}=1\end{array}$ & 7 & 3 & 0.010 & 4.0 \\
\hline W5Q9R7_SHEEP & $\begin{array}{l}\text { Insulin receptor substrate } 4 \mathrm{OS}=\text { Ovis } \\
\text { aries } \mathrm{OX}=9940 \mathrm{GN}=\mathrm{IRS} 4 \mathrm{PE}=4 \mathrm{SV}=1\end{array}$ & 21 & 3 & 0.048 & 2.2 \\
\hline AOAOLOC5K2_LUCCU & $\begin{array}{l}\text { Transient-receptor-potential-like protein } \\
\mathrm{OS}=\text { Lucilia cuprina } \mathrm{OX}=7375 \mathrm{GN}=\mathrm{FF} 38 \_12352 \\
\mathrm{PE}=3 \mathrm{SV}=1\end{array}$ & 20 & 3 & 0.005 & 1.8 \\
\hline AOAOR7F1J7_SHEEP & $\begin{array}{l}\text { Integrin beta OS=Ovis aries OX }=9940 \mathrm{GN}=\text { ITGB4 } \\
\mathrm{PE}=3 \mathrm{SV}=1\end{array}$ & 22 & 3 & 0.012 & 1.9 \\
\hline AOAOF6TAI6_9CORY & $\begin{array}{l}\text { Protein translocase subunit SecA } \\
\text { OS=Corynebacterium } \\
\text { camporealensis } \mathrm{OX}=161,896 \mathrm{GN}=\text { secA2 PE = } 3 \\
\mathrm{SV}=1\end{array}$ & 11 & 3 & 0.020 & 2.1 \\
\hline W5Q867_SHEEP & $\begin{array}{l}\text { Solute carrier family } 12 \text { member } 2 \mathrm{OS}=\text { Ovis } \\
\text { aries } \mathrm{OX}=9940 \mathrm{GN}=\mathrm{SLC} 12 \mathrm{~A} 2 \mathrm{PE}=4 \mathrm{SV}=1\end{array}$ & 18 & 4 & 0.043 & 2.4 \\
\hline AOAOLOC8P6_LUCCU & $\begin{array}{l}\text { Uncharacterized protein OS = Lucilia } \\
\text { cuprina } \mathrm{OX}=7375 \mathrm{GN}=\mathrm{FF} 38 \_06963 \mathrm{PE}=4 \mathrm{SV}=1\end{array}$ & 12 & 4 & 0.046 & 7.5 \\
\hline AOAOLOCKQ7_LUCCU & $\begin{array}{l}\text { Uncharacterized protein OS = Lucilia } \\
\text { cuprina } \mathrm{OX}=7375 \mathrm{GN}=\mathrm{FF} 38 \_01703 \mathrm{PE}=4 \mathrm{SV}=1\end{array}$ & 47 & 4 & 0.045 & 2.1 \\
\hline W5PTP8_SHEEP & $\begin{array}{l}\text { Hexokinase } 2 \mathrm{OS}=\text { Ovis aries } \mathrm{OX}=9940 \mathrm{GN}=\mathrm{HK} 2 \\
\mathrm{PE}=3 \mathrm{SV}=1\end{array}$ & 38 & 5 & 0.025 & 4.0 \\
\hline AOAOLOBM89_LUCCU & $\begin{array}{l}\text { Angiotensin-converting enzyme OS = Lucilia } \\
\text { cuprina } \mathrm{OX}=7375 \mathrm{GN}=\mathrm{FF} 38 \_00036 \mathrm{PE}=3 \mathrm{SV}=1\end{array}$ & 43 & 6 & 0.122 & 2.3 \\
\hline
\end{tabular}




\begin{tabular}{|c|c|c|c|c|c|}
\hline Accession & Protein description & $\begin{array}{l}\text { Peptide } \\
\text { count }\end{array}$ & $\begin{array}{l}\text { Unique } \\
\text { peptides }\end{array}$ & $\begin{array}{l}\text { Anova } \\
\text { (p) }\end{array}$ & $\begin{array}{l}\text { Fold } \\
\text { chang }\end{array}$ \\
\hline AOAOLOCJR7_LUCCU & $\begin{array}{l}\text { Protein shuttle craft OS }=\text { Lucilia } \\
\text { cuprina } \mathrm{OX}=7375 \mathrm{GN}=\mathrm{FF} 38 \_00482 \mathrm{PE}=4 \mathrm{SV}=1\end{array}$ & 13 & 7 & 0.035 & 2.8 \\
\hline AOAOLOCM37_LUCCU & $\begin{array}{l}\text { Myosin heavy chain, non-muscle (Fragment) } \\
\text { OS = Lucilia cuprina OX = } 7375 \text { GN=FF38_03473 } \\
\text { PE = } 3 \mathrm{SV}=1\end{array}$ & 66 & 11 & 0.061 & 1.6 \\
\hline AOAOLOCCG7_LUCCU & $\begin{array}{l}\text { Uncharacterized protein OS = Lucilia } \\
\text { cuprina } \mathrm{OX}=7375 \mathrm{GN}=\mathrm{FF} 38 \_08546 \mathrm{PE}=4 \mathrm{SV}=1\end{array}$ & 63 & 17 & 0.033 & 2.1 \\
\hline \multicolumn{6}{|l|}{ RPCT vs Ctrl } \\
\hline W5PB27_SHEEP & $\begin{array}{l}\text { NADH:ubiquinone oxidoreductase core subunit } \\
\text { S3 OS=Ovis aries OX = } 9940 \mathrm{GN}=\mathrm{NDUFS} 3 \mathrm{PE}=1 \\
\text { SV }=1\end{array}$ & 8 & 1 & 0.013 & 2.2 \\
\hline W5P2V7_SHEEP & $\begin{array}{l}\text { Thyroid hormone receptor beta OS=Ovis } \\
\text { aries } \mathrm{OX}=9940 \mathrm{GN}=\mathrm{THRB} \mathrm{PE}=3 \mathrm{SV}=1\end{array}$ & 7 & 1 & 0.030 & 2.0 \\
\hline W5PQK3_SHEEP & $\begin{array}{l}\text { ATP-dependent 6-phosphofructokinase OS=Ovis } \\
\text { aries } \mathrm{OX}=9940 \mathrm{GN}=\mathrm{PFKL} \mathrm{PE}=3 \mathrm{SV}=1\end{array}$ & 17 & 1 & 0.005 & 2.3 \\
\hline W5PGM3_SHEEP & $\begin{array}{l}\text { Neurocan OS=Ovis aries OX }=9940 \mathrm{GN}=\mathrm{NCAN} \\
\mathrm{PE}=4 \mathrm{SV}=1\end{array}$ & 10 & 1 & 0.024 & 1.9 \\
\hline W5QIA8_SHEEP & $\begin{array}{l}\text { Tyrosine-tRNA ligase OS=Ovis aries } \mathrm{OX}=9940 \\
\mathrm{GN}=\mathrm{YARS} P E=3 \mathrm{SV}=1\end{array}$ & 10 & 1 & 0.028 & 2.8 \\
\hline W5Q7Z1_SHEEP & $\begin{array}{l}\text { Uncharacterized protein OS=Ovis } \\
\text { aries } \mathrm{OX}=9940 \mathrm{PE}=4 \mathrm{SV}=1\end{array}$ & 5 & 1 & 0.014 & 1.6 \\
\hline W5Q1L3_SHEEP & $\begin{array}{l}\text { Zinc finger protein OS=Ovis aries } \mathrm{OX}=9940 \\
\mathrm{GN}=\mathrm{PRDM} 5 \mathrm{PE}=4 \mathrm{SV}=1\end{array}$ & 12 & 1 & 0.030 & 78.1 \\
\hline W5PW19_SHEEP & $\begin{array}{l}\text { Uncharacterized protein OS=Ovis } \\
\text { aries } \mathrm{OX}=9940 \mathrm{PE}=4 \mathrm{SV}=1\end{array}$ & 3 & 1 & 0.041 & 12.8 \\
\hline A0A1Q9FRS2_BACLI & $\begin{array}{l}\text { Rod shape-determining protein RodA } \\
\text { OS=Bacillus licheniformis OX }=1402 \\
\text { GN=BHT94_20645 PE = 3 SV = } 1\end{array}$ & 3 & 1 & 0.017 & 3.9 \\
\hline
\end{tabular}




\begin{tabular}{|c|c|c|c|c|c|}
\hline Accession & Protein description & $\begin{array}{l}\text { Peptide } \\
\text { count }\end{array}$ & $\begin{array}{l}\text { Unique } \\
\text { peptides }\end{array}$ & $\begin{array}{l}\text { Anova } \\
\text { (p) }\end{array}$ & $\begin{array}{l}\text { Fold } \\
\text { change }\end{array}$ \\
\hline A0A1Q9FFL6_BACLI & $\begin{array}{l}\text { Glycerophosphodiester phosphodiesterase } \\
\text { OS=Bacillus licheniformis OX = } 1402 \\
\text { GN=BHT94_13585 PE = 4 SV = } 1\end{array}$ & 4 & 1 & 0.029 & 1.9 \\
\hline W5PG09_SHEEP & $\begin{array}{l}\text { Phosphoglycerate kinase } \mathrm{OS}=\text { Ovis } \\
\text { aries } \mathrm{OX}=9940 \mathrm{GN}=\mathrm{PGK} 2 \mathrm{PE}=3 \mathrm{SV}=1\end{array}$ & 30 & 1 & 0.005 & 4.1 \\
\hline A0A085NY88_ECOLX & $\begin{array}{l}\text { Uncharacterized protein OS = Escherichia } \\
\text { coli OX =562 GN = JD73_24705 PE = 4 SV = } 1\end{array}$ & 5 & 1 & 0.027 & 1.9 \\
\hline W5NZMO_SHEEP & $\begin{array}{l}\text { Uncharacterized protein OS=Ovis } \\
\text { aries } \mathrm{OX}=9940 \mathrm{PE}=4 \mathrm{SV}=1\end{array}$ & 5 & 1 & 0.026 & 1.7 \\
\hline AOAOLOC8H9_LUCCU & $\begin{array}{l}\text { Uncharacterized protein OS = Lucilia } \\
\text { cuprina } \mathrm{OX}=7375 \mathrm{GN}=\mathrm{FF} 38 \_05744 \mathrm{PE}=4 \mathrm{SV}=1\end{array}$ & 6 & 1 & 0.030 & 2.1 \\
\hline W5Q646_SHEEP & $\begin{array}{l}\text { L-lactate dehydrogenase OS=Ovis } \\
\text { aries } \mathrm{OX}=9940 \mathrm{PE}=3 \mathrm{SV}=1\end{array}$ & 10 & 2 & 0.030 & 1.7 \\
\hline W5PLE8_SHEEP & $\begin{array}{l}\text { Glutamate metabotropic receptor } 4 \mathrm{OS}=\text { Ovis } \\
\text { aries } \mathrm{OX}=9940 \mathrm{GN}=\mathrm{GRM} 4 \mathrm{PE}=3 \mathrm{SV}=1\end{array}$ & 8 & 2 & 0.026 & 20.8 \\
\hline A0A126QUY3_9EURY & $\begin{array}{l}\text { Serine-tRNA ligase OS = methanogenic archaeon } \\
\text { mixed culture ISO4-G1 OX = 1,452,364 GN = serS } \\
\mathrm{PE}=3 \mathrm{SV}=1\end{array}$ & 8 & 2 & 0.032 & 1.6 \\
\hline AOAOLOC741_LUCCU & $\begin{array}{l}\text { 1,2-dihydroxy-3-keto-5-methylthiopentene } \\
\text { dioxygenase OS = Lucilia cuprina } \mathrm{OX}=7375 \\
\text { GN=FF38_05497 PE = } 3 \mathrm{SV}=1\end{array}$ & 19 & 2 & 0.027 & 1.8 \\
\hline AOAOLOC855_LUCCU & $\begin{array}{l}\text { Protein penguin OS = Lucilia cuprina } \mathrm{OX}=7375 \\
\mathrm{GN}=\mathrm{FF} 38 \_02127 \mathrm{PE}=4 \mathrm{SV}=1\end{array}$ & 17 & 2 & 0.042 & 2.8 \\
\hline W5PBD8_SHEEP & $\begin{array}{l}\text { Laminin subunit beta } 1 \mathrm{OS}=\text { Ovis aries } \mathrm{OX}=9940 \\
\mathrm{GN}=\mathrm{LAMB} 1 \mathrm{PE}=4 \mathrm{SV}=1\end{array}$ & 21 & 2 & 0.038 & 9.8 \\
\hline W5PUXO_SHEEP & $\begin{array}{l}\text { NADH dehydrogenase [ubiquinone] flavoprotein } \\
1 \text {, mitochondrial OS=Ovis aries OX = 9940 } \\
\text { GN=NDUFV1 PE = } 1 \mathrm{SV}=1\end{array}$ & 18 & 2 & 0.010 & 1.7 \\
\hline
\end{tabular}




\begin{tabular}{|c|c|c|c|c|c|}
\hline Accession & Protein description & $\begin{array}{l}\text { Peptide } \\
\text { count }\end{array}$ & $\begin{array}{l}\text { Unique } \\
\text { peptides }\end{array}$ & $\begin{array}{c}\text { Anova } \\
\text { (p) }\end{array}$ & $\begin{array}{l}\text { Fold } \\
\text { change }\end{array}$ \\
\hline W5P3A4_SHEEP & $\begin{array}{l}\text { Castor zinc finger } 1 \mathrm{OS}=\text { Ovis aries } \mathrm{OX}=9940 \\
\mathrm{GN}=\mathrm{CASZ} 1 \mathrm{PE}=4 \mathrm{SV}=1\end{array}$ & 20 & 3 & 0.006 & 2.5 \\
\hline W5PKB6_SHEEP & $\begin{array}{l}\text { Phosphorylase kinase catalytic subunit gamma } 1 \\
\mathrm{OS}=\text { Ovis aries } \mathrm{OX}=9940 \mathrm{GN}=\mathrm{PHKG} 1 \mathrm{PE}=3 \\
\mathrm{SV}=1\end{array}$ & 14 & 3 & 0.049 & 2.4 \\
\hline AOAOLOCPA2_LUCCU & $\begin{array}{l}\text { Eukaryotic translation initiation factor } 3 \text { subunit } \\
\mathrm{COS}=\text { Lucilia cuprina } \mathrm{OX}=7375 \\
\mathrm{GN}=\mathrm{FF} 38 \_06471 \mathrm{PE}=3 \mathrm{SV}=1\end{array}$ & 16 & 3 & 0.017 & 1.9 \\
\hline W5PK95_SHEEP & $\begin{array}{l}\text { Heterogeneous nuclear ribonucleoprotein } \mathrm{A} 2 / \mathrm{B} 1 \\
\mathrm{OS}=\text { Ovis aries } \mathrm{OX}=9940 \mathrm{GN}=\mathrm{HNRNPA2B} 1 \mathrm{PE}=4 \\
\mathrm{SV}=1\end{array}$ & 11 & 3 & 0.045 & 2.0 \\
\hline W5PI38_SHEEP & $\begin{array}{l}\text { Citrate synthase } \mathrm{OS}=\text { Ovis aries } \mathrm{OX}=9940 \mathrm{GN}=\mathrm{CS} \\
\mathrm{PE}=3 \mathrm{SV}=1\end{array}$ & 15 & 5 & 0.001 & 1.5 \\
\hline AOAOLOC1SO_LUCCU & $\begin{array}{l}\text { Putative vitellogenin receptor OS = Lucilia } \\
\text { cuprina } \mathrm{OX}=7375 \mathrm{GN}=\mathrm{FF} 38 \_00862 \mathrm{PE}=4 \mathrm{SV}=1\end{array}$ & 29 & 7 & 0.046 & 2.2 \\
\hline$R P$ vs $R P C T$ & & & & & \\
\hline W5PIW7_SHEEP & $\begin{array}{l}\text { Prolyl 4-hydroxylase subunit alpha } 3 \mathrm{OS}=\text { Ovis } \\
\text { aries OX }=9940 \mathrm{GN}=\mathrm{P} 4 \mathrm{HA} 3 \mathrm{PE}=4 \mathrm{SV}=1\end{array}$ & 9 & 1 & 0.003 & 6.2 \\
\hline W5Q8KO_SHEEP & $\begin{array}{l}\text { RB binding protein } 6 \text {, ubiquitin ligase } \mathrm{OS}=\text { Ovis } \\
\text { aries } \mathrm{OX}=9940 \mathrm{GN}=\mathrm{RBBP} 6 \mathrm{PE}=4 \mathrm{SV}=1\end{array}$ & 37 & 2 & 0.004 & 4.5 \\
\hline AOAOLOCD96_LUCCU & $\begin{array}{l}\text { Glutactin OS = Lucilia cuprina OX }=7375 \\
\text { GN=FF38_06986 PE }=4 \mathrm{SV}=1\end{array}$ & 15 & 6 & 0.014 & 1.5 \\
\hline$R P C T$ vs $R P$ & & & & & \\
\hline W5Q6F1_SHEEP & $\begin{array}{l}\text { Starch binding domain } 1 \mathrm{OS}=\text { Ovis } \\
\text { aries } \mathrm{OX}=9940 \mathrm{GN}=\mathrm{STBD} 1 \mathrm{PE}=4 \mathrm{SV}=1\end{array}$ & 7 & 1 & 0.025 & 51.9 \\
\hline A0A0F6QXM4_9CORY & $\begin{array}{l}\text { Acetyl-CoA carboxylase, carboxyltransferase } \\
\text { component (Subunits alpha and beta) } \\
\text { OS=Corynebacterium }\end{array}$ & 16 & 1 & 0.031 & 9.2 \\
\hline
\end{tabular}




\begin{tabular}{|c|c|c|c|c|c|}
\hline Accession & Protein description & $\begin{array}{l}\text { Peptide } \\
\text { count }\end{array}$ & $\begin{array}{l}\text { Unique } \\
\text { peptides }\end{array}$ & $\begin{array}{l}\text { Anova } \\
\text { (p) }\end{array}$ & $\begin{array}{l}\text { Fold } \\
\text { change }\end{array}$ \\
\hline & $\begin{array}{l}\text { camporealensis OX = 161,896 GN=NG00_01909 } \\
\mathrm{PE}=4 \mathrm{SV}=1\end{array}$ & & & & \\
\hline A0A0F6TCG0_9CORY & $\begin{array}{l}\text { Chaperone protein DnaK OS=Corynebacterium } \\
\text { camporealensis } \mathrm{OX}=161,896 \mathrm{GN}=\text { dnaK } \mathrm{PE}=2 \\
\mathrm{SV}=1\end{array}$ & 9 & 1 & 0.029 & 4.7 \\
\hline V9R964_9MOLU & $\begin{array}{l}\text { Uncharacterized protein OS = Mycoplasma ovis } \\
\text { str. } \text { Michigan OX = 1,415,773 GN=OVS_02485 } \\
\mathrm{PE}=4 \mathrm{SV}=1\end{array}$ & 12 & 1 & 0.045 & 3.2 \\
\hline AOAOLOC4G2_LUCCU & $\begin{array}{l}\text { Putative WASH complex subunit strumpellin } \\
\mathrm{OS}=\text { Lucilia cuprina OX }=7375 \mathrm{GN}=\mathrm{FF} 38 \_05493 \\
\mathrm{PE}=4 \mathrm{SV}=1\end{array}$ & 37 & 1 & 0.007 & 5.7 \\
\hline W5PINO_SHEEP & $\begin{array}{l}\text { Aldehyde dehydrogenase } 1 \text { family member } A 3 \\
\mathrm{OS}=\text { Ovis aries } \mathrm{OX}=9940 \mathrm{GN}=\mathrm{ALDH} 1 \mathrm{~A} 3 \mathrm{PE}=3 \\
\mathrm{SV}=1\end{array}$ & 6 & 1 & 0.031 & 3.8 \\
\hline W5QD47_SHEEP & $\begin{array}{l}\text { Olfactory receptor OS=Ovis aries OX }=9940 \\
\mathrm{GN}=\mathrm{LOC} 101116220 \mathrm{PE}=3 \mathrm{SV}=1\end{array}$ & 5 & 1 & 0.003 & 5.8 \\
\hline W5P9A0_SHEEP & $\begin{array}{l}\text { Aldehyde dehydrogenase } 5 \text { family member } 11 \\
\mathrm{OS}=\text { Ovis aries } \mathrm{OX}=9940 \mathrm{GN}=\mathrm{ALDH} 5 \mathrm{~A} 1 \mathrm{PE}=4 \\
\mathrm{SV}=1\end{array}$ & 12 & 2 & 0.010 & 9.5 \\
\hline W5P9L9_SHEEP & $\begin{array}{l}\text { Uncharacterized protein } \mathrm{OS}=\text { Ovis } \\
\text { aries } \mathrm{OX}=9940 \mathrm{PE}=4 \mathrm{SV}=1\end{array}$ & 12 & 4 & 0.064 & 2.3 \\
\hline W5P8S8_SHEEP & $\begin{array}{l}\text { Aldehyde dehydrogenase } 1 \text { family member } \mathrm{L} 1 \\
\mathrm{OS}=\text { Ovis aries } \mathrm{OX}=9940 \mathrm{GN}=\mathrm{ALDH} 1 \mathrm{~L} 1 \mathrm{PE}=3 \\
\mathrm{SV}=1\end{array}$ & 20 & 4 & 0.013 & 1.7 \\
\hline AOAOLOBNE9_LUCCU & $\begin{array}{l}\text { Uncharacterized protein OS = Lucilia } \\
\text { cuprina } \mathrm{OX}=7375 \mathrm{GN}=\mathrm{FF} 38 \_12600 \mathrm{PE}=4 \mathrm{SV}=1\end{array}$ & 22 & 4 & 0.106 & 5.4 \\
\hline W5P2C2_SHEEP & $\begin{array}{l}\text { Ankyrin } 3 \text { OS=Ovis aries } \mathrm{OX}=9940 \mathrm{GN}=\mathrm{ANK} 3 \\
\mathrm{PE}=4 \mathrm{SV}=1\end{array}$ & 131 & 14 & 0.031 & 1.6 \\
\hline
\end{tabular}


Table 5. Significant identified proteins with differential abundance following the labelfree approach for the hepatic tissue. Ctrl - Control; RP - Reduced Protein; RPCT Reduced protein with CT treatment.

Accession

Description

$\begin{array}{ccc}\begin{array}{c}\text { Peptide } \\ \text { Unique Anova }\end{array} & \begin{array}{c}\text { Max fold } \\ \text { peptides }\end{array} & \text { (p) }\end{array}$

Ctrl vs RP

A0A085P8V8 ECOLX

Membrane protein OS = Escherichia

coli OX $=562$ GN = JD73_03150 PE $=4$ SV $=1$

Ribosomal protein L14-like protein

BOFZMO_SHEEP

(Fragment) OS=Ovis aries OX $=9940 \mathrm{PE}=2$

8

2

$0.015 \quad 1.5$

$\mathrm{SV}=1$

Uncharacterized protein OS=Ovis

W5P0T3_SHEEP

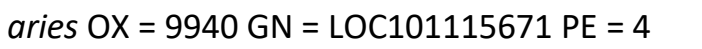

9

3

$0.045 \quad 2.6$

W5PA09_SHEEP

Sulfotransferase OS=Ovis aries OX $=9940$

$\mathrm{PE}=3 \mathrm{SV}=1$

6

1

$0.041 \quad 1.7$

$R P$ vs $C t r l$

W5PF18_SHEEP

Uncharacterized protein OS=Ovis

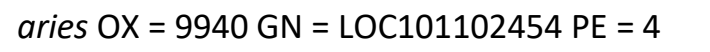

4

2

$0.023 \quad 2.1$

$\mathrm{SV}=1$

Aldehyde dehydrogenase 1 family member

W5PINO_SHEEP A3 OS $=$ Ovis aries OX $=9940 \mathrm{GN}=\mathrm{ALDH} 1 \mathrm{A3}$

$\mathrm{PE}=3 \mathrm{SV}=1$

Family with sequence similarity 91 member

W5PIS1_SHEEP

A1 OS=Ovis aries OX $=9940 \mathrm{GN}=\mathrm{FAM} 91 \mathrm{~A} 1$

11

1

$0.023 \quad 1.9$

$\mathrm{PE}=4 \mathrm{SV}=1$

Uncharacterized protein OS=Ovis

W5PMM4_SHEEP

aries OX $=9940 \mathrm{GN}=\mathrm{LOC} 106990122 \mathrm{PE}=4$

18

1

0.041 Infinity

$\mathrm{SV}=1$

Multiple EGF like domains 11 OS=Ovis

W5Q9R4_SHEEP

aries $\mathrm{OX}=9940 \mathrm{GN}=\mathrm{MEGF1} \mathrm{PE}=4 \mathrm{SV}=1$

3

1

$0.029 \quad 1.6$ 


\begin{tabular}{|c|c|c|c|c|c|}
\hline Accession & Description & $\begin{array}{l}\text { Peptide } \\
\text { count }\end{array}$ & $\begin{array}{l}\text { Unique } \\
\text { peptides }\end{array}$ & $\begin{array}{l}\text { Anova } \\
\text { (p) }\end{array}$ & $\begin{array}{r}\text { Max } \\
\text { chat }\end{array}$ \\
\hline W5QAS6_SHEEP & $\begin{array}{l}\text { Uncharacterized protein OS=Ovis } \\
\text { aries } \mathrm{OX}=9940 \mathrm{PE}=3 \mathrm{SV}=1\end{array}$ & 10 & 1 & 0.418 & 4.3 \\
\hline \multicolumn{6}{|l|}{ Ctrl vs RPCT } \\
\hline AOAOLOBVQ7_LUCCU & $\begin{array}{l}\text { Septin-1 OS = Lucilia cuprina OX }=7375 \\
\text { GN=FF38_02071 PE }=3 \mathrm{SV}=1\end{array}$ & 6 & 1 & 0.037 & 12.1 \\
\hline & Elongation factor 1 alpha protein (Fragment) & & & & \\
\hline E5BB59_LUCCU & $\begin{array}{l}\mathrm{OS}=\text { Lucilia cuprina } \mathrm{OX}=7375 \mathrm{GN}=\mathrm{EF}-1 \mathrm{a} \\
\mathrm{PE}=4 \mathrm{SV}=1\end{array}$ & 4 & 1 & 0.030 & 2.1 \\
\hline & Chromodomain helicase DNA binding protein & & & & \\
\hline W5PVC6_SHEEP & $\begin{array}{l}5 \mathrm{OS}=\text { Ovis aries } \mathrm{OX}=9940 \mathrm{GN}=\mathrm{CHD} 5 \mathrm{PE}=4 \\
\mathrm{SV}=1\end{array}$ & 33 & 5 & 0.043 & 1.5 \\
\hline W5Q3Y8_SHEEP & $\begin{array}{l}\text { Calcium-transporting ATPase OS=Ovis } \\
\text { aries } \mathrm{OX}=9940 \mathrm{GN}=\mathrm{ATP} 2 \mathrm{~A} 2 \mathrm{PE}=3 \mathrm{SV}=1\end{array}$ & 14 & 2 & 0.012 & 2.2 \\
\hline W5QDD0_SHEEP & $\begin{array}{l}\text { Uncharacterized protein OS=Ovis } \\
\text { aries OX = } 9940 \mathrm{GN}=\mathrm{LOC} 101108092 \mathrm{PE}=4 \\
\mathrm{SV}=1\end{array}$ & 14 & 3 & 0.001 & 7.0 \\
\hline W5QGJ5_SHEEP & $\begin{array}{l}\text { Single-pass membrane protein with coiled- } \\
\text { coil domains } 1 \mathrm{OS}=\text { Ovis aries } \mathrm{OX}=9940 \\
\mathrm{GN}=\mathrm{SMCO} 1 \mathrm{PE}=4 \mathrm{SV}=1\end{array}$ & 8 & 2 & 0.044 & 1.8 \\
\hline W5QJ04_SHEEP & $\begin{array}{l}\text { Protein phosphatase, } \mathrm{Mg} 2+/ \mathrm{Mn} 2+ \\
\text { dependent } 1 \mathrm{~A} O \mathrm{OS}=\text { Ovis aries } \mathrm{OX}=9940 \\
\mathrm{GN}=\mathrm{PPM} 1 \mathrm{~A} \mathrm{PE}=3 \mathrm{SV}=1\end{array}$ & 6 & 1 & 0.017 & 3.0 \\
\hline \multicolumn{6}{|l|}{ RPCT vs Ctrl } \\
\hline & AT-hook DNA binding motif containing 1 & & & & \\
\hline W5NZM6_SHEEP & $\begin{array}{l}\mathrm{OS}=\text { Ovis aries } \mathrm{OX}=9940 \mathrm{GN}=\mathrm{AHDC1} \mathrm{PE}=4 \\
\mathrm{SV}=1\end{array}$ & 20 & 1 & 0.010 & 1.5 \\
\hline W5P9J8_SHEEP & $\begin{array}{l}\text { Biliverdin reductase } \mathrm{B} O \mathrm{OS}=\text { Ovis } \\
\text { aries } \mathrm{OX}=9940 \mathrm{GN}=\mathrm{BLVRB} \mathrm{PE}=4 \mathrm{SV}=1\end{array}$ & 4 & 1 & 0.014 & 1.8 \\
\hline
\end{tabular}




\begin{tabular}{|c|c|c|c|c|c|}
\hline Accession & Description & $\begin{array}{l}\text { Peptide } \\
\text { count }\end{array}$ & $\begin{array}{l}\text { Unique } \\
\text { peptides }\end{array}$ & $\begin{array}{l}\text { Anova } \\
\text { (p) }\end{array}$ & $\begin{array}{l}\text { Max fold } \\
\text { change }\end{array}$ \\
\hline W5PHZ3_SHEEP & $\begin{array}{l}\text { UDP-glucuronosyltransferase OS=Ovis } \\
\text { aries } \mathrm{OX}=9940 \mathrm{PE}=3 \mathrm{SV}=1\end{array}$ & 13 & 1 & 0.024 & 2.8 \\
\hline W5PTG8_SHEEP & $\begin{array}{l}\text { Peptidase } \mathrm{M} 20 \text { domain-containing protein } 2 \\
\mathrm{OS}=\text { Ovis aries } \mathrm{OX}=9940 \mathrm{GN}=\mathrm{PM} 2 \mathrm{D} 2 \mathrm{PE}=3 \\
\mathrm{SV}=1\end{array}$ & 3 & 1 & 0.038 & 2.8 \\
\hline W5Q6N7_SHEEP & $\begin{array}{l}\text { Thioredoxin domain containing } 5 \mathrm{OS}=\text { Ovis } \\
\text { aries } \mathrm{OX}=9940 \mathrm{GN}=\mathrm{TXNDC5} \mathrm{PE}=4 \mathrm{SV}=1\end{array}$ & 6 & 2 & 0.013 & 1.7 \\
\hline
\end{tabular}

$R P$ vs $R P C T$

Uncharacterized protein OS = Lucilia

AOAOLOBZS2_LUCCU cuprina OX $=7375$ GN=FF38_12973 PE $=4$

SV $=1$

$\begin{array}{lll}7 & 0.024 & 7.1\end{array}$

$\mathrm{BCL} 2$ like 13 OS=Ovis aries $\mathrm{OX}=9940$

$\mathrm{GN}=\mathrm{BCL} 2 \mathrm{~L} 13 \mathrm{PE}=4 \mathrm{SV}=1$

$1 \quad 0.048 \quad 7.9$

$R P C T$ vs $R P$

$\begin{array}{ll} & \begin{array}{l}\text { Odorant receptor OS= Lucilia } \\ \text { A0A0L0C661_LUCCU } \\ \text { cuprina OX=7375 GN=FF38_03119 PE=3 } \\ \text { SV }=1\end{array}\end{array}$

Table 6. Significant identified proteins with differential abundance following the label-

free approach for the adipose tissue. Ctrl - Control; RP - Reduced Protein; RPCT -

Reduced protein with condensed tannin treatment.

Accession
Description

$\begin{array}{cc}\begin{array}{c}\text { Peptide } \\ \text { count }\end{array} & \begin{array}{c}\text { Unique } \\ \text { peptides }\end{array}\end{array}$

Anova Max fold

(p) change

Ctrl vs RPCT

\begin{tabular}{|c|c|c|c|c|}
\hline AOAOLOBXP6 LUCCU & $\begin{array}{l}\text { Uncharacterized protein OS = Lucilia } \\
\text { cuprina } \mathrm{OX}=7375 \mathrm{GN}=\mathrm{FF} 38 \quad 04845 \mathrm{PE}=4\end{array}$ & 7 & 1 & 0.026 \\
\hline & (5) & & & \\
\hline
\end{tabular}




\begin{tabular}{|c|c|c|c|c|c|}
\hline Accession & Description & $\begin{array}{l}\text { Peptide } \\
\text { count }\end{array}$ & $\begin{array}{l}\text { Unique } \\
\text { peptides }\end{array}$ & $\begin{array}{l}\text { Anova } \\
\text { (p) }\end{array}$ & $\begin{array}{c}\text { Max fold } \\
\text { change }\end{array}$ \\
\hline AOAOLOBVE2_LUCCU & $\begin{array}{l}\text { Uncharacterized protein OS = Lucilia } \\
\text { cuprina } \mathrm{OX}=7375 \mathrm{GN}=\mathrm{FF} 38 \_07428 \mathrm{PE}=3 \\
\mathrm{SV}=1\end{array}$ & 5 & 1 & 0.027 & 1.5 \\
\hline \multicolumn{6}{|l|}{ RPCT vs Ctrl } \\
\hline CRYAB_SHEEP & $\begin{array}{l}\text { Alpha-crystallin B chain OS=Ovis } \\
\text { aries } \mathrm{OX}=9940 \mathrm{GN}=\mathrm{CRYAB} P E=2 \mathrm{SV}=1\end{array}$ & 8 & 1 & 0.003 & 4.2 \\
\hline W5NUTO_SHEEP & $\begin{array}{l}\text { Caveolae associated protein } 1 \mathrm{OS}=\text { Ovis } \\
\text { aries } \mathrm{OX}=9940 \mathrm{GN}=\mathrm{CAVIN} 1 \mathrm{PE}=4 \mathrm{SV}=1\end{array}$ & 24 & 2 & 0.035 & 1.8 \\
\hline W5NYE7_SHEEP & $\begin{array}{l}\text { DExD-box helicase } 52 \mathrm{OS}=\text { Ovis } \\
\text { aries } \mathrm{OX}=9940 \mathrm{GN}=\mathrm{DDX} 52 \mathrm{PE}=4 \mathrm{SV}=1\end{array}$ & 11 & 1 & 0.027 & 3.4 \\
\hline W5NWW2_SHEEP & $\begin{array}{l}\text { Elastin microfibril interfacer } 3 \mathrm{OS}=\text { Ovis } \\
\text { aries } \mathrm{OX}=9940 \mathrm{GN}=\mathrm{EMILIN} 3 \mathrm{PE}=4 \mathrm{SV}=1\end{array}$ & 9 & 1 & 0.022 & 1.9 \\
\hline W5Q9G8_SHEEP & $\begin{array}{l}\text { Enoyl-CoA delta isomerase } 1 \mathrm{OS}=\text { Ovis } \\
\text { aries } \mathrm{OX}=9940 \mathrm{GN}=\mathrm{ECI} 1 \mathrm{PE}=4 \mathrm{SV}=1\end{array}$ & 9 & 2 & 0.006 & 3.0 \\
\hline W5Q540_SHEEP & $\begin{array}{l}\text { Hydroxyacylglutathione hydrolase } \mathrm{OS}=\text { Ovis } \\
\text { aries } \mathrm{OX}=9940 \mathrm{GN}=\mathrm{HAGH} \mathrm{PE}=3 \mathrm{SV}=1\end{array}$ & 6 & 2 & 0.020 & 1.6 \\
\hline W5Q5F1_SHEEP & $\begin{array}{l}\text { Macrophage erythroblast attacher } \mathrm{OS}=\text { Ovis } \\
\text { aries } \mathrm{OX}=9940 \mathrm{GN}=\mathrm{MAEA} \mathrm{PE}=4 \mathrm{SV}=1\end{array}$ & 12 & 1 & 0.019 & 1.6 \\
\hline W5PD20_SHEEP & $\begin{array}{l}\text { SIVA1 apoptosis inducing factor OS=Ovis } \\
\text { aries } \mathrm{OX}=9940 \mathrm{GN}=\mathrm{SIVA} 1 \mathrm{PE}=4 \mathrm{SV}=1\end{array}$ & 7 & 1 & 0.029 & 1.6 \\
\hline AOAOLOBNKO_LUCCU & $\begin{array}{l}\text { Uncharacterized protein (Fragment) } \\
\text { OS = Lucilia cuprina OX = } 7375 \\
\text { GN=FF38_09800 PE = 4 SV = } 1\end{array}$ & 57 & 5 & 0.043 & 1.5 \\
\hline$R P$ vs $R P C T$ & & & & & \\
\hline W5QB88_SHEEP & $\begin{array}{l}\text { Collagen type } \mathrm{XI} \text { alpha } 1 \text { chain } \mathrm{OS}=\text { Ovis } \\
\text { aries } \mathrm{OX}=9940 \mathrm{GN}=\mathrm{COL} 11 \mathrm{~A} 1 \mathrm{PE}=4 \mathrm{SV}=1\end{array}$ & 30 & 2 & 0.026 & 5.2 \\
\hline
\end{tabular}




\begin{tabular}{|c|c|c|c|c|c|}
\hline Accession & Description & $\begin{array}{l}\text { Peptide } \\
\text { count }\end{array}$ & $\begin{array}{l}\text { Unique } \\
\text { peptides }\end{array}$ & $\begin{array}{c}\text { Anova } \\
\text { (p) }\end{array}$ & $\begin{array}{c}\text { Max fold } \\
\text { change }\end{array}$ \\
\hline AOAOLOBWX3_LUCCU & $\begin{array}{l}\text { Putative Apoptosis inhibitor } 5 \text { OS = Lucilia } \\
\text { cuprina OX = } 7375 \text { GN=FF38_08888 PE = } 4 \\
\text { SV }=1\end{array}$ & 14 & 2 & 0.036 & 3.2 \\
\hline A0A1Q9FFE4_BACLI & $\begin{array}{l}\text { Uncharacterized protein OS=Bacillus } \\
\text { licheniformis OX = } 1402 \mathrm{GN}=\mathrm{BHT} 94 \_13195 \\
\mathrm{PE}=4 \mathrm{SV}=1\end{array}$ & 10 & 1 & 0.020 & 2.3 \\
\hline \multicolumn{6}{|l|}{$R P$ vs Ctrl } \\
\hline W5Q7R8_SHEEP & $\begin{array}{l}\text { Junction plakoglobin OS=Ovis } \\
\text { aries } \mathrm{OX}=9940 \mathrm{GN}=\mathrm{JUP} \mathrm{PE}=4 \mathrm{SV}=1\end{array}$ & 8 & 1 & 0.037 & 23.4 \\
\hline AOAOLOC2T7_LUCCU & $\begin{array}{l}\text { Uncharacterized protein OS = Lucilia } \\
\text { cuprina OX = } 7375 \text { GN=FF38_01365 PE = } 3 \\
\text { SV }=1\end{array}$ & 14 & 2 & 0.039 & 2.1 \\
\hline W5PG36_SHEEP & $\begin{array}{l}\text { Voltage dependent anion channel } 2 \mathrm{OS}=\text { Ovis } \\
\text { aries } \mathrm{OX}=9940 \mathrm{GN}=\mathrm{VDAC2} \mathrm{PE}=4 \mathrm{SV}=1\end{array}$ & 8 & 2 & 0.035 & 1.6 \\
\hline
\end{tabular}

\subsubsection{Longissimus lumborum muscle tissue}

Using the label-free approach, 78 proteins were identified with differential abundance in the LL muscle. Control lambs had higher abundance of proteins such as myosin light chain (MYL10) in comparison to RP muscle, whereas RP lambs had higher abundance of hemopexin (HPX) and succinate dehydrogenase flavoprotein subunit (SDHA) vs control. In comparison to the RPCT lambs, control had higher abundance of myosin heavy chain, hexokinase 2 (HK2) and insulin receptor substrate 4 (IRS4); whereas CT-treated lambs had higher abundance of glycolytic proteins such as Llactate dehydrogenase and citrate synthase (CS). Regarding the experimental groups comparison, RP lambs had higher abundance of three proteins such as glutactin, and RPCT had higher abundance of acetyl-CoA carboxylase, aldehyde dehydrogenase proteins (ALDH1A3, ALDH5A1 and ALDH1L1).

\subsubsection{Hepatic tissue}


The hepatic tissue had 25 proteins identified with differential abundance between groups. Control had higher abundance of 4 proteins vs RP, like ribosomal protein L14-like protein. RP on the other hand, had higher abundance of 6 proteins, including aldehyde dehydrogenase 1 family member A3 (ALDH1A3). Control had higher abundance of 7 proteins vs RPCT, whereas the latter group had higher abundance of 5 proteins, among them biliverdin reductase B (BLVRB) in comparison to control. Lesser differences were found in the RP vs RPCT group comparison, with only 3 proteins identified with differential expression.

\subsubsection{Adipose tissue}

The label-free approach conducted on the perirenal adipose tissue resulted in the identification of 17 proteins with differential abundance among the 2300 identified in this tissue. The control group has higher abundance of 2 uncharacterized proteins vs RPCT, whereas the latter had higher abundance of 9 proteins, among them enoyl-CoA delta isomerase 1 (ECI1) and hydroxyacylglutathione hydrolase (HAGH) compared to the former. RP had higher abundance of 3 proteins vs control and the inverse relation had no proteins with differential abundance. Compared to RPCT, RP lambs had higher abundance of 3 proteins, such as collagen type XI alpha 1 chain (COL11A1) and putative apoptosis inhibitor 5 .

\section{Discussion}

Ruminant production systems demand increasingly sustainable practices that do not compromise animal performance and overall farm profitability. Taking advantage of abundant resources such as Cistus ladanifer and its CT could be a viable option in the reduction of dietary protein sources utilization particularly if it could simultaneously increase the protein efficiency and lower feed prices. By performing a proteome analysis of the tissues of lambs fed with different protein levels and CT-treated diets, the objective of this work is to highlight the effects of these CT-treatment and different levels of dietary protein on lamb tissues and assert its effect on animal metabolism and the final product. In addition, using these approaches also allows performing tissue proteome characterization. 


\subsection{Proteome characterization}

To our knowledge, this is the first study that reports the proteome characterization of the perirenal fat tissue of sheep. The omics studies performed so far regarding perirenal fat of sheep have been done using transcriptomics [24,25]. However, a proteomic approach has been done before in other small and large ruminants. The perirenal fat of 1-month old goat kids has been studied and authors identified 654 proteins. Seventy-two of these proteins were found only in this white adipose tissue, and not in others such as the subcutaneous fat tissue. These uniquely identified proteins were mainly related to RNA and DNA processing, DNA repair and protein translation [26]. In our study, we identified a significantly higher number of proteins in the perirenal fat of older lambs. This difference could be related to the optimized protocol we used for the adipose tissue particularly. Also, while the latter authors identified over $73 \%$ of proteins of perirenal fat involved in metabolic processes, we found $26.5 \%$ in this tissue of lambs. Because ruminant visceral adipose tissue is highly involved in lipid metabolism and energy balance, high percentage of metabolic process proteins would be expected [27].

Regarding the other two tissues, their proteome has been previously reported [28,29]. Yu et al. [28] have reported the proteome of longissimus lumborum after $48 \mathrm{~h}$ postmortem, at which point it is considered meat and not muscle tissue. More recently, Ferreira et al. [30] have reported the identification of 668 proteins in the gastrocnemius muscle proteome of lambs from three different breeds. The higher number of proteins identified in our study most likely occur due to different muscles and enhanced protein databases. The longissimus thoracis of bulls has been reported to have most BP annotations corresponding to metabolic process [17], with $32.8 \%$ of the total hits, which is much higher than what we have obtained for the longissimus lumborum of Merino Branco lambs (23.5\%), most likely due to different metabolic rates and muscle development between species. Likewise, Miller et al. [29] have reported the hepatic tissue proteome to be comprised mostly by metabolic process annotations (46.9\%), which is much higher than what we have obtained in this study $(31.10 \%)$. However, MF such as catalytic activity (44.1\%) are more comparable to the present study (40.6\%). The differences found can arise from the fact that the latter authors used three different breeds. 


\subsection{Differential protein abundance}

In the following sections, a detailed description on the effect of diet in tissue proteomes is provided. For this purpose, information outputs of both approaches are combined for interpretation of differential protein abundance. Moreover, given the nature of relative quantification, the comparison of differential protein abundance is made comparing two groups at a time, similarly to what was previously reported $[\underline{29}, \underline{30}]$.

\subsubsection{Longissimus lumborum muscle}

\subsubsection{Energy metabolism proteins}

Phosphoglycerate mutase (PGAM2), a protein involved in the glycolysis pathway, was found in higher abundance in both treatments with lower dietary protein in comparison to control. This probably reflects the large metabolic availability of glucose in lambs fed RP and RPCT diets, because in these diets the soybean meal was replaced by corn and citrus pulp, which supplied more glucose and gluconeogenic precursors to lamb metabolism. This would also explain the higher abundance of phosphoglycerate kinase (PGK2) and L-lactate dehydrogenase, which are also involved in the glycolysis pathway, and were identified with higher abundance in the lambs fed the RPCT diet. Higher abundance of glycolytic proteins such as $\beta$-enolase 3, 3-fructose-1,6-biphosphate aldolase A and triosephosphate isomerase, has been previously reported in the semitendinosus muscle of Japanese Black Cattle raised on concentrate (grain) feed in comparison to those fed on ryegrass hay [31]. Interestingly, insulin receptor substrate 4 (IRS4) was highly abundant in control vs RPCT. IRS4 is not a substrate for insulin, possibly due to a competition with IRS1 and IRS2 [32], which suggests that the differential abundance in the present study is independent of insulin signalling. Indeed, this protein is also a negative regulator of the insulin-like growth factor 1 (IGF-1), which stimulates muscle development [33] and whose expression is positively correlated to muscle fibre diameter and shear force in the longissimus dorsi of Hu sheep [34]. These indicators have long been related to reduced meat tenderness [35], which will be addressed in Section 4.2.1.3. The higher abundance of glucose and glycolytic enzymes might also be related to increased intramuscular fat deposition in lambs fed on lower dietary protein. Both 
PGK2 and PGAM2 enzymes are highly abundant in the muscle of RPCT lambs in comparison to the control treatment, which yields higher amounts of pyruvate available to enter the citric acid cycle. This metabolite is then converted into acetylCoA. Additionally, this group also had higher abundance of citrate synthase (vs control) whose activity yields citrate [36], which increases the activity of acetyl CoA carboxylase (highly abundant in RPCT vs RP). The acetyl CoA carboxylase gene (ACACA) expression is reported to increase in the semitendinous muscle of lambs raised intensively whereas grazing lambs had the lowest expression [37]. In addition, the ACACA gene has been positively correlated with the IMF content in the longissimus muscle of Korean steers [38]. The relation between these protein abundances seems to suggest that lambs fed on lower dietary protein have increased intramuscular fat. Fatty acid profiling of the muscle tissue should delve further into this hypothesis.

\subsubsection{Stress response proteins}

Authors have previously reported that including Cistus ladanifer in lamb diets improves meat oxidative stability, protecting it from lipid oxidation [39]. The RPCT group had an abundance of several aldehyde dehydrogenase family proteins vs RP (e.g. ALDH1A3). These are involved in the breakdown of toxic aldehydes that result from lipid peroxidation [40]. These aldehydes are partly responsible for postmortem lipid oxidation which in turn causes off-flavour in meat [41]. Hence, higher abundance of ALDH proteins would benefit shelf life of meat from lambs fed CTtreated diets. Moreover, this group had higher abundance of oxidative metabolism proteins such as NADH dehydrogenase [ubiquinone] flavoprotein 1 (NDUFV1) vs control. This protein had higher abundance in the muscle of growing Damara vs Dorper lambs [30], the former having darker meat than either Dorper or Australian Merino lambs [42]. It is important to point out that in the present study, CT have been included in small amounts, as a means to treat soybean meal only. Hence, the extent to which these effects -antioxidative stability and meat colour- might be seen in the final product quality parameters is uncertain, and requires further studies.

Hemopexin (HPX) was highly abundant in RP vs control. This protein partakes in tissue haem detoxification [43]. Additionally, it had the lowest abundance of proteins related to oxidative defences such as those described earlier for RPCT lambs 
(aldehyde dehydrogenase proteins). Rats fed diets with different protein concentrations corroborate our results: adequate protein feeding (13.8\%) induced higher oxidative stress comparing to both other groups (25.7 and 51.3\%) [44]. It could therefore be assumed that, since protein and its metabolites (e.g. some amino acids such as arginine) have antioxidant activity [45], RP lambs have lower anti-oxidative capacity in comparison to either RPCT or control who had higher protein availability.

\subsubsection{Contractile apparatus proteins}

Tropomyosin 1 (TPMN1), a contractile apparatus protein, was found with higher abundance in the muscle tissue of control lambs. In addition, myosin light chain (MLC) 10 and myosin heavy chain being a protein involved in muscle contractility along with tropomyosin - had higher abundance in the muscle tissue of control lambs vs either RP and RPCT. Control lambs were the heaviest at the time of slaughter; therefore, their higher muscle development is in agreement with higher abundance of structural and contractile apparatus proteins. Almeida et al. [17] have related several isoforms of MLC to higher metabolic and muscle synthesis rates of Alentejana cattle bulls with continuous growth, in comparison to discontinuous growth ones. Additionally, Ferreira et al. [30] have found higher abundance of myosin and tropomyosin proteins in the muscle of Dorper lambs (selected for meat production and high growth rates), in comparison to two other breeds: Australian Merino and Damara. In the present study, control lambs had the highest growth rate and feed

efficiency when compared to RP lambs, hence higher abundance of proteins related to muscle development and function would be expected. Moreover, higher abundance of structural proteins is negatively correlated to meat tenderness [46]. Thus, it could be possible that control lambs have less tender meat compared to both other groups. This, however, does not exclude the necessity of validation through shear-force assessment in future studies.

\subsubsection{Hepatic tissue}

\subsubsection{Stress response proteins}

Flavin reductase (NADPH) isoform $\mathrm{X} 1$ and superoxide dismutase $\left[\mathrm{Cu} \_\mathrm{Zn}\right]$ were found in higher abundance in the hepatic tissue of RPCT lambs, in addition to 
biliverdin reductase B (BLVRB) that was also identified with higher abundance vs control. These enzymes represent major defences against oxidative stress, namely by performing heme catabolism and eliminating ROS (e.g. $\mathrm{H}_{2} \mathrm{O}_{2}$ ). It seems therefore that in addition to improve antioxidant status of muscle/meat, $\mathrm{CT}$ also contribute to maintain oxidative stability and control lipid peroxidation products in the hepatic tissue. Lambs fed with diets containing 6.4\% (DM basis) quebracho tannins have been previously reported to have enhanced antioxidant status of their hepatic tissue in comparison to control [] $]$.

Lambs of the RP group showed an increased abundance of aldehyde dehydrogenase 1 (ALDH1A3) and BCL2 proteins in the hepatic tissue vs control and RPCT, respectively. The former protein has already been described as part of the response against oxidative stress and the latter partakes in the defence against heat stress and inhibits programmed cell death [47]. In fact, the upregulation of the aldehyde dehydrogenase 2 gene in the liver of goats fed a high concentrate diet has been associated with mitochondrial dysfunction [48]. Moreover, the lower abundance of aldehyde dehydrogenase has been related to limited hepatic fatty acid degradation in feed-deprived dairy cows [49]. In turn, its abundance was high in Palmera (susceptible to weight loss) goat's mammary gland secretory tissue after a period of feed restriction [50]. Taken together, these results point towards increased oxidative stability in the hepatic tissue of lambs fed with CT-treated soybean meal. In RP lambs however, differential protein abundance suggests higher susceptibility.

\subsubsection{Sulphur amino acid metabolism}

Two different spots of adenosylhomocysteinase (LOC101112245) were found to be highly abundant in control lambs when compared to either RP or RPCT lambs. This enzyme catalyses a reaction that yields adenosine and homocysteine from S-adenosylL-homocysteine [51]. It has been previously reported to be downregulated in the liver of obese mice [52]. Since adenosylhomocysteine has an inhibitory effect over transmethylation reactions in the liver [53], it would seem that lower dietary protein causes adenosylhomocysteine accumulation which could impair reactions involved in amino acid metabolism and gluconeogenesis. This occurs regardless of the inclusion of CT. Additionally, ribosomal protein L14-like protein and sulfotransferase proteins also had higher abundance in the hepatic tissue of control lambs vs RP. This increases 
the insight on the effect of low dietary protein: control lambs seem to have higher yields of homocysteine from s-adenosylhomocysteine hydrolysis, which in turn increases the rates of methionine and cysteine regeneration. Both of these amino acids are essential for the synthesis of ribosomal proteins such as the one mentioned above and when combined with the higher abundance of sulfotransferase, it suggests that the difference of dietary protein in the present study affected sulphur metabolism as well, most likely due to increased availability/absorption of amino acids. Interestingly, authors have previously reported that sheep fed with CT containing forage increase post-ruminal absorption of sulphur-containing amino acids [54]. However, the difference of dietary protein between control and RPCT lambs could have surpassed the beneficial effect of CT on the absorption of these amino acids. Using complementary techniques such as metabolomics [55] or amino acid quantification [56] would be useful to further explore the extent to which CT and dietary protein affect sulphur metabolism.

\subsubsection{Iron and carbohydrate metabolism}

Four different spots of transferrin (TF) were found to be highly abundant in both RP and RPCT lambs in comparison to control. This protein is responsible for systemic iron transport and is involved in the major mechanism of iron uptake by the liver [57]. High dietary protein is reported to decrease the iron concentration in the liver of calves [58]. Contrarily, growing Baladi kids fed with $13 \% \mathrm{CP}$ had increased $\mathrm{Fe}$ concentrations compared to those fed with $10 \% \mathrm{CP}$ [59]. According to Ferreira et al. [30], ferritin (an iron storage protein) is highly abundant in the muscle of restricted vs growing Australian Merino lambs. In our study, increased abundance of transferrin points towards higher hepatic iron uptake due to lower dietary protein, regardless of CT treatment. Indeed, RP lambs had higher abundance of HPX vs control in the muscle, which indicates muscle haem detoxification, and consecutively lessened haem-Fe in RP muscle. This is in accordance with higher TF abundance, since iron is then transported and stored in the liver. The mechanism behind higher Fe storage due to lower dietary protein is unclear, but complementary information such as mineral profiling [60] would be helpful to fully understand this difference.

Aldose 1-epimerase (GALM) was found to be highly abundant in control and RP vs RPCT hepatic tissue. This enzyme catalyses the reaction that converts $\alpha$-D-glucose 
into $\beta$-D-glucose, and vice-versa; which seems to be a direct effect of CT over carbohydrate metabolism. It has long been reported that CT decrease carbohydrate digestibility [61]. Accordingly, when testing different doses of a Cistus ladanifer extract, other authors have justified the negative relation between phenolic concentration and soluble degradable fraction of the dry matter of CT-treated soybean meal with an eventual binding of CT to carbohydrates [8]. However, because SBM was treated with CT before feed mixing, CT are expected to almost entirely complexified with SBM protein. Nonetheless, lower carbohydrate absorption and availability in RPCT lambs could result in lessened hepatic abundance of enzymes such as GALM.

\subsubsection{Perirenal adipose tissue}

\subsubsection{Lipid metabolism}

To our knowledge, the ovine perirenal adipose tissue is understudied using proteomics tools. It is a white adipose tissue (WAT), although it has brown and beige adipose tissue properties in the earlier stages of life for mammals. It has high metabolic activity in comparison to other adipose tissue depots such as subcutaneous fat [62]. Lipid metabolism proteins, related to fatty acid metabolism were expected to be identified, which was the case for fatty acid synthase (FASN) that was found to have lower abundance in control vs either RP or RPCT lambs. It has been described that pigs fed with high dietary protein $(18 \% \mathrm{CP})$, have decreased adipocyte size in subcutaneous fat, as well as lipogenesis downregulation and reduced backfat thickness in comparison to pigs fed with 14\% CP [63]. In the previously mentioned study, high dietary protein diets downregulated the FAS gene in pigs slaughtered at 60 and $100 \mathrm{~kg}$ of live weight. Although swine metabolism cannot be extrapolated to ovine metabolism, it can be inferred that the results obtained in our study for FASN are comparable to the results obtained for pigs fed on different protein levels. This increased adipose tissue deposition is in accordance to what was previously mentioned for the intramuscular fat of these lambs, where control lambs have lower fatty acids deposition.

Enoyl-CoA hydratase 1 (ECH1) was highly abundant in control lamb perirenal adipose tissue vs either RP or RPCT. The ECHS1 (analogous gene to ECH1) gene has 
been reported to be downregulated in the adipose tissue of steers, which was related with their improved capacity to accumulate IMF in comparison to entire males [64]. Thus, apparently control lambs have less adipogenic activity and/or fat depots, since they have higher abundance of this enzyme, involved in $\beta$-oxidation of fatty acids. Likewise, aconitate hydratase (ACO2) was highly abundant in the adipose tissue of control lambs. This enzyme participates in the citric acid (i.e. TCA) cycle by catalysing the reversible reactions that convert citrate into isocitrate. This is of relevance because it means that control WAT adipocytes are oxidizing carbohydrates and/or fatty acids via the TCA cycle [65] to a greater extent than the remaining groups, thus confirming lessened synthesis of fatty acids in the adipose tissue of control lambs. This occurs most likely because of the increased glucose supply of RP and RPCT lambs which would increase adipogenicity in this tissue. Indeed, collagen (COL11A1 and COL4A1) was highly abundant in both previous groups compared to control lambs. In WAT, collagen is mostly present in the extracellular matrix [24]. The higher abundance of matrix proteins in this tissue keeps up with fat tissue accumulation in lambs with lower dietary protein.

\subsubsection{Cell signalling pathways}

Putative apoptosis inhibitor 5 (FF38_08888) had higher abundance in RP vs RPCT whereas apoptosis inducing factor (SIVA1) had higher abundance in the WAT of RPCT vs control lambs. It is an odd relation, because tannins are known to act as antioxidants, which would inhibit apoptosis via the inactivation of apoptosis-causing ROS. Since adipocyte apoptosis is anti-adipogenic [66], it would be expected that RPCT lambs have lower synthesis of perirenal adipose tissue. However, this was not the case. In fact, these lambs have higher abundance (vs control) of caveolae associated protein 1 (CAVIN1), a protein that has been related with adipose tissue development in other ruminant species [12]. Thus, this differential abundance seems to suggest that the presence of $\mathrm{CT}$ in diets with $12 \% \mathrm{CP}$ may increase the adipocyte turnover rate.

\subsubsection{Stress response}

It is noteworthy to point out that that RPCT lambs had higher abundance of hydroxyacylglutathione hydrolase (HAGH) in the WAT, which is a protein involved 
in the synthesis of glutathione, an antioxidant. Hence, in agreement with the different papers that report an enhancement of oxidative stability of ruminant tissues caused by dietary inclusion of tannins [2, $\underline{4}]$, it seems that CT also enhance the oxidative stability of visceral adipose tissues such as the perirenal fat.

\subsection{Tissue interactions}

In the previous sections, the differential protein abundance of three tissues were discussed. In Fig. 11, a summary of the effect of CT in the muscle, hepatic and adipose tissues is presented. Some of the results obtained could have a relation among tissues. Indeed, the RPCT group often had abundant proteins related to oxidative stress response. If our initial premise regarding muscle carbohydrate metabolism is correct, RPCT lambs have higher synthesis of intramuscular fat. If so, RPCT meat (i.e. edible tissues) benefits from increased antioxidant activity, to avoid the negative effect of $\beta$-oxidation of fatty acids. This would explain why these lambs have higher abundance of stress response proteins such as aldehyde dehydrogenase across all tissues, to perform tissue ROS detox. In turn, it would enhance the oxidative stability of edible tissues such as muscle, which has been extensively reported to be an effect of feeding animals with CT. 


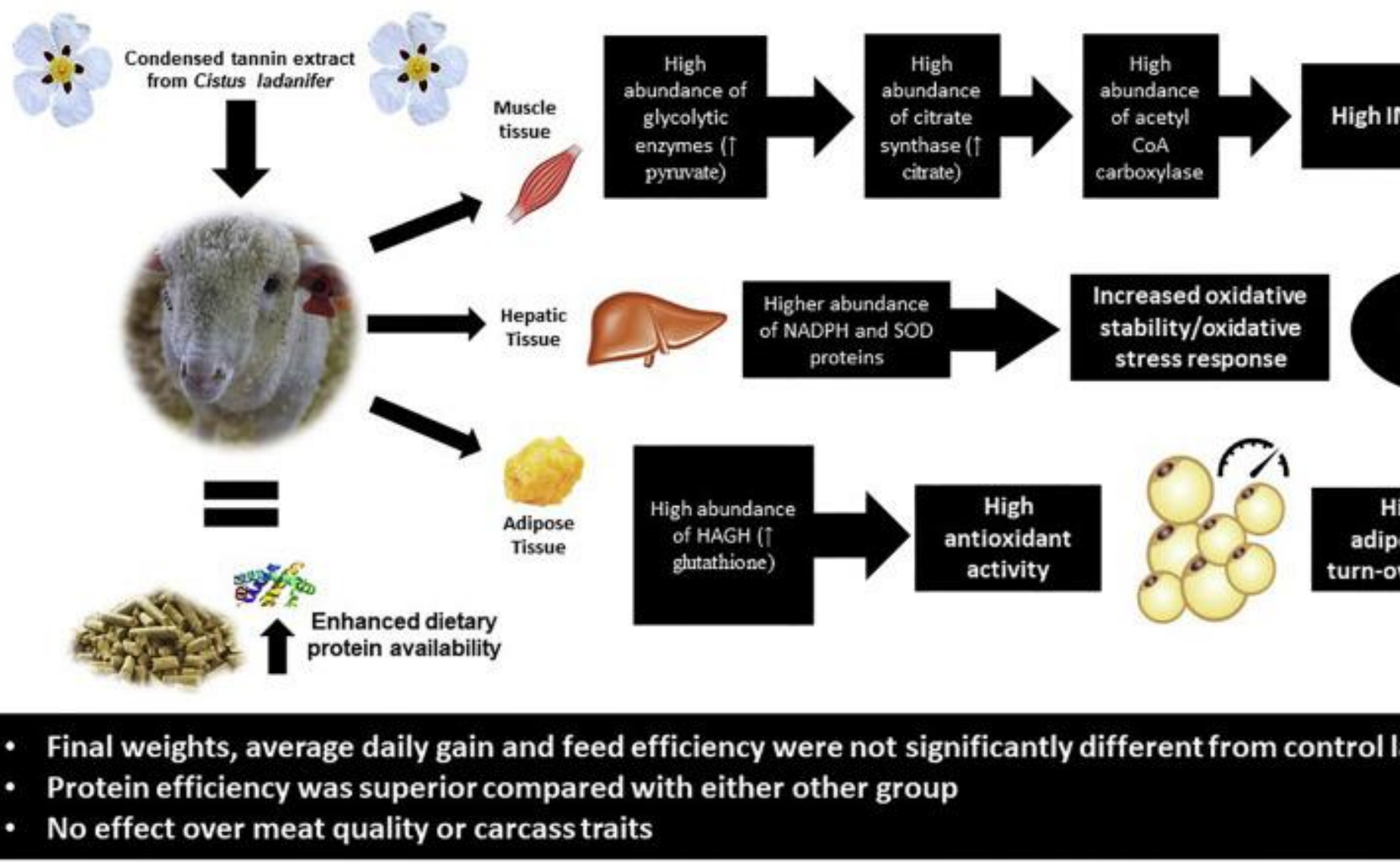

1. Download: Download high-res image (346KB)

2. Download : Download full-size image

Fig. 11. Summary of the effect of CT on the muscle, hepatic and adipose tissues of lambs. Interestingly, the RP group had abundant hemopexin in its muscle, which is responsible for haem detox and transport towards the liver. In the latter tissue, these lambs had higher abundance of biliverdin reductase B (BLVRB), a protein that partakes in haem catabolism. Moreover, they had high abundance of transferrin proteins in the hepatic tissue, which clearly indicates high hepatic Fe uptake. Lower dietary protein induces higher rates of haem turnover and catabolism from tissues. Haem is transported to the liver from the muscle by hemopexin. In the liver, BLVRB acts in its degradation and the resulting Fe is stored in ferritin. Overall, it appears that the effect of lower dietary protein in haem metabolism occurs regardless of the inclusion of CT.

\section{Conclusions and future perspectives}


The effect of CT on the proteome of sheep fed with $120 \mathrm{~g} \mathrm{CP} / \mathrm{kg}$ DM was demonstrated. It resulted mainly in the enhancement of the oxidative stability of the different tissues, which warrants further research to confirm these results. Major differences found between tissues, however, result from increased dietary availability of glucose, because RP and RPCT lambs were fed with higher percentages of corn and beat pulp.

In addition, lower dietary protein had major effects in amino acid and protein metabolism in the hepatic tissue particularly at the level of sulphur amino acid metabolism. The increased dietary protein of control lambs was reflected in higher protein synthesis rates in this tissue. Lambs of reduced dietary protein had higher abundance of transferrin which increases the hepatic Fe uptake in the liver.

In the adipose tissue, differential abundance of fatty acid metabolism proteins does not reflect the lack of significant differences in adipose tissue depots and could be caused instead by higher fatty acid/adipocyte turnover rates in RP and RPCT groups.

Finally, CT-treatment of lower dietary protein diets has proven to generate similar results to diets with higher dietary protein regarding animal performance. In addition, this proteomics approach revealed that the antioxidant status of these animal's tissues has improved, which is highly desirable for the meat industry since it could potentially increase the shelf life of lamb meat products.

In the future, it would be very interesting to carry out other omics approaches, namely metabolomics, to confirm the hypothesis that our work has now brought up regarding the modulation of carbohydrate metabolism in the muscle and sulphur amino acid in the hepatic tissue. Moreover, the mineral, amino acid and fatty acid profiles of these samples would be of interest to complement the information we have provided. This would help zoom in on the differences of the present study and help differentiate between the effect of lower dietary protein and lower dietary protein with CT treatment.

\section{Acknowledgements}


Financial support from the Alentejo 2020 program through the FEDER to project CistusRumen (ALT20-03-0145-FEDER-000023) is acknowledged for the animal experiment. Author DM Ribeiro acknowledges the internship fellowship by the Luxembourg Institute of Science and Technology and the $\mathrm{PhD}$ grant provided by the FCT (Fundação para a Ciência e Tecnologia) ref. SFRH/BD/143992/2019. Authors DM Ribeiro and AM Almeida acknowledge funding from unit program LEAF - Linking Landscape, Environment, Agriculture and Food Research Centre (ISA - University of Lisbon) funded by the FCT (Fundação para a Ciência e Tecnologia, Lisbon, Portugal) Strategic Project (UID/AGR/04129). The authors thank David Soldado for providing the photographs taken during the animal trial.

\section{Credit author statement}

Authors EJ, JS-S, MTD and RJB designed the animal production study. Authors MTD, JS-S and KP conducted the animal production trial. Authors AM and JR designed the proteomics study. Authors DMR, SP, CCL and JR conducted the proteomics and mass spectrometry laboratory work and bioinformatics analysis. Authors EJ, MTD, JS-S, RJB and KP analysed animal production data. Authors DMR and AMA analysed and interpreted proteomics data. Authors DMR and AMA wrote the manuscript. All authors read and agreed on the final version of the manuscript.

\section{Appendix A. Supplementary data}

Download all supplementary files included with this article Help

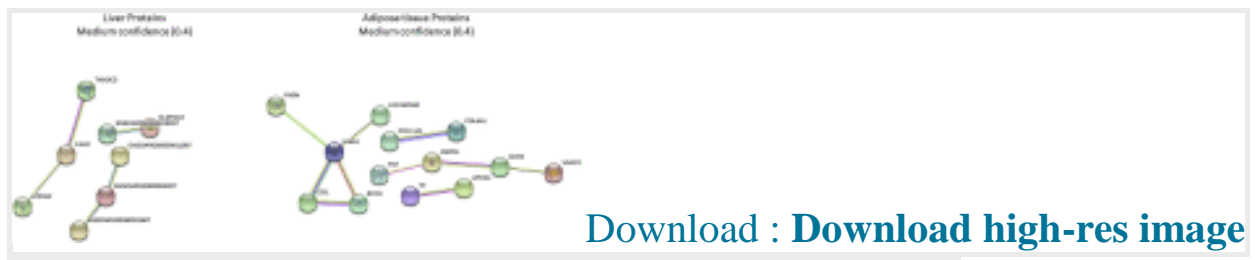

(154KB)Download : Download full-size image (41KB)

Supplementary material 1

Download : Download Acrobat PDF file (437KB)

Supplementary material 2 
Download : Download Acrobat PDF file (1MB)

Supplementary material 3

Download : Download Acrobat PDF file (1MB)

Supplementary material 4

Download : Download Comma Separated Value file (680KB)

Supplementary material 5

Download : Download Comma Separated Value file (733KB)

Supplementary material 6

Download : Download Comma Separated Value file (1MB)

Supplementary material 7

\section{References}

[1]

M.I. Ferraz de Oliveira, E. Lamy, M.N. Bugalho, M. Vaz, C. Pinheiro, M. Cancela d'Abreu, F. Capela e Silva, E. Sales-Baptista

Assessing foraging strategies of herbivores in Mediterranean oak woodlands: a review of key issues and selected methodologies

Agrofor. Syst., 87 (2013), pp. 1421-1437, 10.1007/s10457-013-9648-3

CrossRefView Record in ScopusGoogle Scholar

[2]

E. Jerónimo, C. Pinheiro, E. Lamy, M. Teresa Dentinho, E. Sales-Baptista, O. Lopes, F. Capela Silva

Tannins in ruminant nutrition: Impact on animal performance and quality of edible products C.A. Combs (Ed.), Tann. Biochem. Food Sources Nutr. Prop (1st ed.), Nova Science Publishers, Inc., New York (2016), pp. 121-168

View Record in ScopusGoogle Scholar

[3]

A.K. Patra, J. Saxena

Exploitation of dietary tannins to improve rumen metabolism and ruminant nutrition J. Sci. Food Agric., 91 (2011), pp. 24-37, 10.1002/jsfa.4152 


\section{CrossRefView Record in ScopusGoogle Scholar}

[4]

E. Jerónimo, S.P. Alves, M.T.P. Dentinho, S.V. Martins, J.A.M. Prates, V. Vasta, J. Santos-

Silva, R.J.B. Bessa

Effect of grape seed extract, Cistus ladanifer L., and Vegetable oil supplementation on fatty acid composition of abomasal digesta and intramuscular fat of lambs

J. Agric. Food Chem., 58 (2010), pp. 10710-10721, 10.1021/if1021626

\section{CrossRefView Record in ScopusGoogle Scholar}

\section{[5]}

V. Vasta, A. Priolo, M. Scerra, K.G. Hallett, J.D. Wood, O. Doran

$\Delta 9$ Desaturase protein expression and fatty acid composition of Longissimus Dorsi muscle in lambs fed green herbage or concentrate with or without added tannins

Meat Sci., 82 (2009), pp. 357-364, 10.1016/j.meatsci.2009.02.007

ArticleDownload PDFView Record in ScopusGoogle Scholar

[6]

P. López-Andrés, G. Luciano, V. Vasta, T.M. Gibson, L. Biondi, A. Priolo, I. Mueller-Harvey

Dietary quebracho tannins are not absorbed, but increase the antioxidant capacity of liver and plasma in sheep

Br. J. Nutr., 110 (2013), pp. 632-639, 10.1017/\$0007114512005703

View Record in ScopusGoogle Scholar

E. Lamy, L. Rodrigues, O. Guerreiro, D. Soldado, A. Francisco, M. Lima, F.C. e Silva, O. Lopes, J. Santos-Silva, E. Jerónimo

Changes in salivary protein composition of lambs supplemented with aerial parts and condensed tannins: extract from Cistus ladanifer L. - a preliminary study

Agrofor. Syst., 4 (2019), 10.1007/s10457-019-00386-4

Google Scholar

M.T.P. Dentinho, O.C. Moreira, M.S. Pereira, R.J.B. Bessa

The use of a tannin crude extract from Cistus ladanifer L. to protect soya-bean protein from degradation in the rumen

Animal, 1 (2007), pp. 645-650, 10.1017/S1751731107689745 


\section{$\underline{\text { ArticleDownload PDFCrossRefView Record in ScopusGoogle Scholar }}$}

M.T.P. Dentinho, A.T. Belo, R.J.B. Bessa

Digestion, ruminal fermentation and microbial nitrogen supply in sheep fed soybean meal treated with Cistus ladanifer L. tannins

Small Rumin. Res., 119 (2014), pp. 57-64, 10.1016/j.smallrumres.2014.02.012

ArticleDownload PDFView Record in ScopusGoogle Scholar

[10]

J. Santos-Silva, R.J.B. Bessa, F. Santos Silva

Effect of genotype, feeding system and slaughter weight on the quality of light lambs: II. Fatty acid composition of meat

Livestock Prod. Science., 77 (2002), pp. 187-194

ArticleDownload PDFView Record in ScopusGoogle Scholar

National Research Council (NRC)

Nutrient requirements of sheep

(6th edition), The National Academies Press, Washington, DC, USA (1985)

Google Scholar

D.M. Ribeiro, S. Planchon, C.C. Leclercq, K. Raundrup, S.P. Alves, R.J.B. Bessa, J. Renaut, A.M. Al meida

The muscular, hepatic and adipose tissues proteomes in muskox (Ovibos moschatus): differences between males and females

J. Proteome, 208 (2019), p. 103480, 10.1016/j.jprot.2019.103480

ArticleDownload PDFView Record in ScopusGoogle Scholar

N.J. Kruger

The Bradford method for protein quantitation

Protein Protoc. Handb. (1996), 10.1007/978-1-60327-259-9 4

$\underline{\text { Google Scholar }}$ 
A.L. Skibiel, M. Zachut, B.C. do Amaral, Y. Levin, G.E. Dahl

Liver proteomic analysis of postpartum Holstein cows exposed to heat stress or cooling conditions during the dry period

J. Dairy Sci., 101 (2018), pp. 705-716, 10.3168/jds.2017-13258

$\underline{\text { ArticleDownload PDFCrossRefView Record in ScopusGoogle Scholar }}$

H.A. Hakimov, S. Walters, T.C. Wright, R.G. Meidinger, C.P. Verschoor, M. Gadish, D.K.Y. Chiu, M. V. Strömvik, C.W. Forsberg, S.P. Golovan

Application of iTRAQ to catalogue the skeletal muscle proteome in pigs and assessment of effects of gender and diet dephytinization

Proteomics., 9 (2009), pp. 4000-4016, 10.1002/pmic.200900049

CrossRefView Record in ScopusGoogle Scholar

T. Bohn, S. Planchon, C.C. Leclercq, J. Renaut, J. Mihaly, G. Beke, R. Rühl

Proteomic responses of carotenoid and retinol administration to Mongolian gerbils

Food Funct., 9 (2018), pp. 3835-3844, 10.1039/C8FO00278A

View Record in ScopusGoogle Scholar

A.M. Almeida, P. Nanni, A.M. Ferreira, C. Fortes, J. Grossmann, R.J.B. Bessa, P. Costa

The longissimus thoracis muscle proteome in Alentejana bulls as affected by growth path

J. Proteome, 152 (2017), pp. 206-215, 10.1016/i.jprot.2016.10.020

$\underline{\text { ArticleDownload PDFView Record in ScopusGoogle Scholar }}$ 
H. Mi, A. Muruganujan, P.D. Thomas

PANTHER in 2013: Modeling the evolution of gene function, and other gene attributes, in the context of phylogenetic trees

Nucleic Acids Res., 41 (2013), pp. 377-386, 10.1093/nar/gks1118

$\underline{\text { Google Scholar }}$

R. Core Team

R: A language and Environment for Statistical Computing

R Foundation for Statistical Computing, Vienna, Austria (2014)

URL

http://www.R-project.org/

$\underline{\text { Google Scholar }}$

Gregory

R. Warnes, Ben Bolker, Lodewijk Bonebakker, Robert Gentleman, Wolfgang Huber, Andy Liaw, T homas Lumley, Martin Maechler, Arni Magnusson, Steffen Moeller, Marc Schwartz, Bill Venables

gplots: Various R Programming Tools for Plotting Data

(2020)

R package version 3.0.3

Google Scholar 
D. Szklarczyk, A.L. Gable, D. Lyon, A. Junge, S. Wyder, J. Huerta-

Cepas, M. Simonovic, N.T. Doncheva, J.H. Morris, P. Bork, L.J. Jensen, C. von Mering

STRING v11: protein-protein association networks with increased coverage, supporting functional discovery in genome-wide experimental datasets

Nucleic Acids Res., 47 (2019 Jan), pp. D607-D613

CrossRefView Record in ScopusGoogle Scholar

E.W. Deutsch, A. Csordas, Z. Sun, A. Jarnuczak, Y. Perez-

Riverol, T. Ternent, D.S. Campbell, M. Bernal-

Llinares, S. Okuda, S. Kawano, R.L. Moritz, J.J. Carver, M. Wang, Y. Ishihama, N. Bandeira, H. Her mjakob, J.A. Vizcaíno

The ProteomeXchange consortium in 2017: supporting the cultural change in proteomics public data deposition

Nucleic Acids Res., 45 (2017), pp. D1100-D1106, 10.1093/nar/gkw936

CrossRefView Record in ScopusGoogle Scholar

J.A. Vizcaíno, A. Csordas, N. Del-Toro, J.A. Dianes, J. Griss, I. Lavidas, G. Mayer, Y. Perez-

Riverol, F. Reisinger, T. Ternent, Q.W. Xu, R. Wang, H. Hermjakob

2016 update of the PRIDE database and its related tools

Nucleic Acids Res., 44 (2016), pp. D447-D456, 10.1093/nar/gkv1145

CrossRefView Record in ScopusGoogle Scholar

B. Li, L. Qiao, L. An, W. Wang, J. Liu, Y. Ren, Y. Pan, J. Jing, W. Liu

Transcriptome analysis of adipose tissues from two fat-tailed sheep breeds reveals key genes involved in fat deposition

BMC Genomics, 19 (2018), pp. 1-13, 10.1186/s12864-018-4747-1 
A. Suárez-Vega, J.J. Arranz, V. Pérez, L.F. de la Fuente, J. Mateo, B. Gutiérrez-Gil

Early adipose deposits in sheep: comparative analysis of the perirenal fat transcriptome of Assaf and Churra suckling lambs

Anim. Genet., 49 (2018), pp. 605-617, 10.1111/age.12725

CrossRefView Record in ScopusGoogle Scholar

L. Restelli, M.C. Codrea, G. Savoini, F. Ceciliani, E. Bendixen

LC-MS/MS analysis of visceral and subcutaneous adipose tissue proteomes in young goats with focus on innate immunity and inflammation related proteins

J. Proteome, 108 (2014), pp. 295-305, 10.1016/j.jprot.2014.05.027

ArticleDownload PDFView Record in ScopusGoogle Scholar

J.M. Romao, W. Jin, M. He, T. McAllister, L.L. Guan

Elucidation of molecular mechanisms of physiological variations between bovine subcutaneous and visceral fat depots under different nutritional regimes

PLoS One, 8 (2013), pp. 1-14, 10.1371/journal.pone.0083211

CrossRefView Record in ScopusGoogle Scholar

T.Y. Yu, J.D. Morton, S. Clerens, J.M. Dyer

In-depth characterisation of the lamb meat proteome from longissimus lumborum

J. Proteome, 6 (2015), pp. 28-41 
B. Miller, N. Selevsek, J. Grossmann, T. Kilminster, T. Scanlon, M. Daniels, P. Nanni, J. Milton, C. Oldham, J. Greeff, A. Chapwanya, D. Bergfelt, A.M. de Almeida

Ovine liver proteome: assessing mechanisms of seasonal weight loss tolerance between merino and Damara sheep

J. Proteome, 191 (2019), pp. 180-190, 10.1016/j.jprot.2018.02.018

ArticleDownload PDFView Record in ScopusGoogle Scholar

A.M. Ferreira, J. Grossmann, C. Fortes, T. Kilminster, T. Scanlon, J. Milton, J. Greeff, C. Oldham, P. Nanni, A.M. Almeida

The sheep (Ovis aries) muscle proteome: decoding the mechanisms of tolerance to seasonal weight loss using label-free proteomics

J. Proteome, 161 (2017), pp. 57-67, 10.1016/j.jprot.2017.03.020

ArticleDownload PDFView Record in ScopusGoogle Scholar

M. Shibata, K. Matsumoto, M. Oe, M. Ohnishi-

Kameyama, K. Ojima, I. Nakajima, S. Muroya, K. Chikuni

Differential expression of the skeletal muscle proteome in grazed cattle

J. Anim. Sci., 87 (2009), pp. 2700-2708, 10.2527/jas.2008-1486

CrossRefView Record in ScopusGoogle Scholar

S. Schreyer, D. Ledwig, I. Rakatzi, I. Klöting, J. Eckel 
Insulin receptor substrate- 4 is expressed in muscle tissue without acting as a substrate for the insulin receptor

Endocrinology., 144 (2003), pp. 1211-1218, 10.1210/en.2002-220723

View Record in ScopusGoogle Scholar

J. Li, A.J. Forhead, M.J. Dauncey, R.S. Gilmour, A.L. Fowden

Control of growth hormone receptor and insulin-like growth factor-l expression by cortisol in ovine fetal skeletal muscle

J. Physiol., 541 (2002), pp. 581-589, 10.1113/iphysiol.2002.016402

CrossRefView Record in ScopusGoogle Scholar

R. Su, W. Sun, D. Li, Q.Z. Wang, X.Y. Lv, H.H. Musa, L. Chen, Y.F. Zhang, W.Z. Wu

Association between DLK1 and IGF-I gene expression and meat quality in sheep

Genet. Mol. Res., 13 (2014), pp. 10308-10319, 10.4238/2014.December.4.26

View Record in ScopusGoogle Scholar

S.C. SEIDEMAN, M. KOOHMARAIE, J.D. CROUSE

The influence of muscle Fiber size on tenderness in A-maturity heifers

J. Food Qual., 11 (1988), pp. 27-34, 10.1111/j.1745-4557.1988.tb00862.x

CrossRefView Record in ScopusGoogle Scholar

G. Wiegand, S.J. Remington 
Citrate synthase: structure, control, and mechanism

Annu. Rev. Biophys. Biophys. Chem., 15 (1986), pp. 97-

117, 10.1146/annurev.bb.15.060186.000525

\section{CrossRefView Record in ScopusGoogle Scholar}

E. Dervishi, C. Serrano, M. Joy, M. Serrano, C. Rodellar, J.H. Calvo

The effect of feeding system in the expression of genes related with fat metabolism in semitendinous muscle in sheep

Meat Sci., 89 (2011), pp. 91-97, 10.1016/j.meatsci.2011.04.003

ArticleDownload PDFView Record in ScopusGoogle Scholar

J. Jeong, E.G. Kwon, S.K. Im, K.S. Seo, M. Baik

Expression of fat deposition and fat removal genes is associated with intramuscular fat content in longissimus dorsi muscle of Korean cattle steers

J. Anim. Sci., 90 (2012), pp. 2044-2053, 10.2527/jas.2011-4753

CrossRefView Record in ScopusGoogle Scholar

E. Jerónimo, C.M.M. Alfaia, S.P. Alves, M.T.P. Dentinho, J.A.M. Prates, V. Vasta, J. SantosSilva, R.J.B. Bessa

Effect of dietary grape seed extract and Cistus ladanifer L. in combination with vegetable oil supplementation on lamb meat quality

Meat Sci., 92 (2012), pp. 841-847, 10.1016/j.meatsci.2012.07.011

ArticleDownload PDFView Record in ScopusGoogle Scholar 
D. Conklin, R. Prough, A. Bhatanagar

Aldehyde metabolism in the cardiovascular system

Mol. BioSyst., 3 (2007), pp. 136-150, 10.1039/b612702a

View Record in ScopusGoogle Scholar

E.N. Ponnampalam, T. Plozza, M.G. Kerr, N. Linden, M. Mitchell, A.E.D.A. Bekhit, J.L. Jacobs, D.L. Hopkins

Interaction of diet and long ageing period on lipid oxidation and colour stability of lamb meat Meat Sci., 129 (2017), pp. 43-49, 10.1016/i.meatsci.2017.02.008

$\underline{\text { ArticleDownload PDFView Record in ScopusGoogle Scholar }}$

A.M. Almeida, T. Kilminster, T. Scanlon, S.S. Araújo, J. Milton, C. Oldham, J.C. Greeff

Assessing carcass and meat characteristics of Damara, Dorper and Australian merino lambs under restricted feeding

Trop. Anim. Health Prod., 45 (2013), pp. 1305-1311, 10.1007/s11250-013-0361-z

CrossRefView Record in ScopusGoogle Scholar

E. Tolosano, F. Altruda

Hemopexin: structure, function, and regulation

DNA Cell Biol., 21 (2002), pp. 297-306, 10.1089/104454902753759717

CrossRefView Record in ScopusGoogle Scholar 
K.J. Petzke, A. Elsner, J. Proll, F. Thielecke, C.C. Metges

Long-term high protein intake does not increase oxidative stress in rats

J. Nutr., 130 (2000), pp. 2889-2896, 10.1093/jn/130.12.2889

\section{CrossRefView Record in ScopusGoogle Scholar}

T. Arrigo, S. Leonardi, C. Cuppari, S. Manti, A. Lanzafame, G. D’Angelo, E. Gitto, L. Marseglia, C. S alpietro

Role of the diet as a link between oxidative stress and liver diseases

World J. Gastroenterol., 21 (2015), pp. 384-395, 10.3748/wig.v21.i2.384

CrossRefView Record in ScopusGoogle Scholar

G. Paredi, S. Raboni, E. Bendixen, A.M. de Almeida, A. Mozzarelli

'Muscle to meat' molecular events and technological transformations: the proteomics insight J. Proteome, 75 (2012), pp. 4275-4289, 10.1016/j.jprot.2012.04.011

$\underline{\text { ArticleDownload PDFView Record in ScopusGoogle Scholar }}$

C. Berasain, J. Castillo, M.J. Perugorria, M.U. Latasa, J. Prieto, M.A. Avila

Inflammation and liver Cancer

Ann. N. Y. Acad. Sci., 1155 (2009), pp. 206-221, 10.1111/i.1749-6632.2009.03704.x

CrossRefView Record in ScopusGoogle Scholar

J. Tian, H. Dong, Y. Ni, R. Cong, R. Zhao, Y. Duanmu, Y. Zhang, S. Tao

Comparative proteomic analysis of the effects of high-concentrate diet on the hepatic metabolism and inflammatory response in lactating dairy goats

J. Anim. Sci. Biotechnol., 7 (2016), pp. 1-11, 10.1186/s40104-016-0065-0

View Record in ScopusGoogle Scholar 
B. Kuhla, D. Albrecht, S. Kuhla, C.C. Metges

Proteome analysis of fatty liver in feed-deprived dairy cows reveals interaction of fuel sensing, calcium, fatty acid, and glycogen metabolism

Physiol. Genomics, 37 (2009), pp. 88-98, 10.1152/physiolgenomics.90381.2008

\section{CrossRefView Record in ScopusGoogle Scholar}

L.E. Hernández-

Castellano, A.M. Ferreira, P. Nanni, J. Grossmann, A. Argüello, J. Capote, G. Cai, J. Lippolis, N. Cas tro, A.M. de Almeida

The goat (Capra hircus) mammary gland secretory tissue proteome as influenced by weight loss: a study using label free proteomics

J. Proteome, 145 (2016), pp. 60-69, 10.1016/j.jprot.2016.03.030

ArticleDownload PDFView Record in ScopusGoogle Scholar

M.A. Turner, X. Yang, D. Yin, K. Kuczera, R.T. Borchardt, P.L. Howell

Structure and function of S-adenosylhomocysteine hydrolase

Cell Biochem. Biophys., 33 (2000), pp. 101-125, 10.1385/CBB:33:2:101

View Record in ScopusGoogle Scholar

K.U. Yun, C.S. Ryu, J.M. Oh, C.H. Kim, K.S. Lee, C.H. Lee, H.S. Lee, B.H. Kim, S.K. Kim

Plasma homocysteine level and hepatic sulfur amino acid metabolism in mice fed a high-fat diet

Eur. J. Nutr., 52 (2013), pp. 127-134, 10.1007/s00394-011-0294-0

CrossRefView Record in ScopusGoogle Scholar

T.O. Eloranta

Tissue distribution of S-Adenosylmethionine and S-Adenosylhomocysteine in the rat J. Biochem., 166 (1977), pp. 521-529

CrossRefView Record in ScopusGoogle Scholar 
W.C. McNabbl, G.C. Waghorn, T.N. Barry, I.D. Shelton

The effect of condensed tannins in Lotus pedunculatus on the digestion and metabolism of methionine, cystine and inorganic Sulphur in sheep

Br. J. Nutr., 70 (1993), pp. 647-661, 10.1079/BJN19930155

\section{CrossRefGoogle Scholar}

M. Palma, T. Scanlon, T. Kilminster, J. Milton, C. Oldham, J. Greeff, M. Matzapetakis, A.M. Almei da

The hepatic and skeletal muscle ovine metabolomes as affected by weight loss: a study in three sheep breeds using NMR-metabolomics

Sci. Rep., 6 (2016), pp. 1-11, 10.1038/srep39120

View Record in ScopusGoogle Scholar

D.M. Ribeiro, M.S. Madeira, T. Kilminster, T. Scanlon, C. Oldham, J. Greeff, J.P.B. Freire, M.P. Mo urato, J.A.M. Prates, A.M. Almeida

Amino acid profiles of muscle and liver tissues of Australian Merino, Damara and Dorper lambs under restricted feeding

J. Anim. Physiol. Anim. Nutr. (Berl). (2019), pp. 1-8, 10.1111/ipn.13148

CrossRefView Record in ScopusGoogle Scholar

E.R. Anderson, Y.M. Shah

Iron homeostasis in the liver

Compr. Physiol., 3 (2013), pp. 315-330, 10.1002/cphy.c120016

CrossRefView Record in ScopusGoogle Scholar

J.W. Spears, R.W. Harvey, L.J. Samsell

Effects of dietary nickel and protein on growth, nitrogen metabolism and tissue concentrations of nickel, iron, zinc, manganese and copper in calves

J. Nutr. (1986), 10.1093/jn/116.10.1873

$\underline{\text { Google Scholar }}$

M.M. Abdelrahman, R.S. Aljumaah 
Dietary protein level and performance of growing Baladi kids

Iran. J. Vet. Res., 15 (2014), pp. 353-358, 10.22099/ijvr.2014.2591

View Record in ScopusGoogle Scholar

D.M. Ribeiro, T. Scanlon, T. Kilminster, C.F. Martins, J. Greeff, J. Milton, C. Oldham, J.P.B. Freire, M.P. Mourato, A.M. de Almeida

Mineral profiling of muscle and hepatic tissues of Australian merino, Damara and Dorper lambs: Effect of weight loss

J. Anim. Physiol. Anim. Nutr., 0 (2020), pp. 1-8, 10.1111/jpn.13339

CrossRefView Record in ScopusGoogle Scholar

T.N. Barry, T.R. Manley

Interrelationships between the concentrations of total condensed tannin, free condensed tannin and lignin in Lotus sp. and their possible consequences in ruminant nutrition

J. Sci. Food Agric., 37 (1986), pp. 248-254, 10.1002/jsfa.2740370309

CrossRefView Record in ScopusGoogle Scholar

F. Ceciliani, C. Lecchi, J. Bazile, M. Bonnet

Proteomics research in the adipose tissue

Proteomics Domest. Anim. From Farm Syst. Biol. (2018), pp. 233-254, 10.1007/978-3-319-

$\underline{69682-9 \quad 12}$

CrossRefView Record in ScopusGoogle Scholar

S. Zhao, J. Wang, X. Song, X. Zhang, C. Ge, S. Gao

Impact of dietary protein on lipid metabolism-related gene expression in porcine adipose tissue

Nutr. Metab., 7 (2010), pp. 1-13, 10.1186/1743-7075-7-6

View Record in ScopusGoogle Scholar

Y.Y. Zhang, H.B. Wang, Y.N. Wang, H.C. Wang, S. Zhang, J.Y. Hong, H.F. Guo, D. Chen, Y. Yang, L. S en Zan 
Transcriptome analysis of mRNA and microRNAs in intramuscular fat tissues of castrated and intact male Chinese Qinchuan cattle

PLoS One, 12 (2017), pp. 1-25, 10.1371/journal.pone.0185961

CrossRefView Record in ScopusGoogle Scholar

C.M. Kusminski, P.E. Scherer

Mitochondrial dysfunction in white adipose tissue

Trends Endocrinol. Metab., 23 (2012), pp. 435-443, 10.1016/j.tem.2012.06.004

$\underline{\text { ArticleDownload PDFView Record in ScopusGoogle Scholar }}$

M. Khalilpourfarshbafi, K. Gholami, D.D. Murugan, M.Z. Abdul Sattar, N.A. Abdullah

Differential effects of dietary flavonoids on adipogenesis

Eur. J. Nutr., 58 (2019), pp. 5-25, 10.1007/s00394-018-1663-8

CrossRefView Record in ScopusGoogle Scholar

M.T.P. Dentinho, K. Paulos, A. Francisco, A.T. Belo, E. Jerónimo, J. Almeida, R.J.B. Bessa, J. Santos -Silva

Effect of soybean meal treatment with Cistus ladanifer condensed tannins in growth performance, carcass and meat quality of lambs.

Livestock Science, 236 (2020), 10.1016/j.livsci.2020.104021

In press

$\underline{\text { Google Scholar }}$ 